PONTIFÍCIA UNIVERSIDADE CATÓLICA DO RIO DE JANEIRO

\title{
A influência de lojas conceito na percepção de marca e na atitude do consumidor Caso Havaianas
}

\section{Fernanda Cotrim Meirelles}

Trabalho de Conclusão de Curso

Centro de CIÊNCIAS SOCIAIS - CCS

DEPARTAMENTO DE ADMINISTRAÇÃo

Graduação em Administração de Empresas 


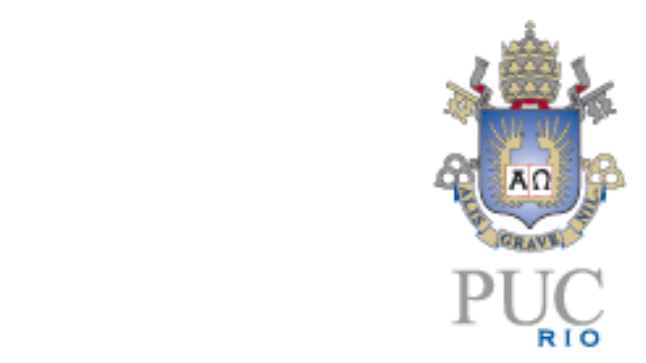

Fernanda Cotrim Meirelles

A influência de lojas conceito na percepção de marca e na atitude do consumidor

Caso Havaianas

Trabalho de Conclusão de Curso

Trabalho de Conclusão de Curso, apresentado ao programa de graduação em Administração da PUC-Rio como requisito parcial para a obtenção do título de graduação em Administração.

Orientador(a): Bárbara Levy

Rio de Janeiro, dezembro de 2019. 


\section{Agradecimentos}

Gostaria de agradecer à minha família por todo o apoio, segurança, orientação e amor. Em especial aos meus pais, Thomaz Meirelles e Gilda Cotrim, por me ensinarem a colocar organização, cuidado e dedicação em tudo que realizo. Também aos meus avós, Antônio Meirelles e Anna Célia Meirelles, por serem uma fonte inesgotável de conhecimento, compreensão e carinho.

Agradeço aos meus melhores amigos e minhas amigas incríveis que desde a escola torcem por mim e vibram com as minhas conquistas, com menção especial a Gabriel Daiha, Matheus Lourenço, Yan Azevedo, Leon França, Guilherme Menezes, Isadora Secchin, Julia Sève, Isadora Paganoto, Mayara Lídia, Luisa Toledo, Izabela Salles, e Yasmin Venâncio. Muito obrigada ao meu namorado, Vinicius Oliveira, por me incentivar e encorajar a ir em busca dos meus sonhos todos os dias. Agradeço também à minha parceira de trabalhos na PUC, Juliana Alves, e ao time dos estagiários SCJ por tornarem o dia a dia mais leve e divertido.

Gostaria de agradecer à minha orientadora, Bárbara Levy, por me auxiliar e guiar nesse processo com um olhar crítico e cuidadoso. Por fim, agradeço a todos os professores da PUC e aos profissionais do estágio que me transmitiram conhecimento e me proporcionaram experiências e aprendizados essenciais para a minha formação como administradora.

Muito obrigada a todos. 


\section{Resumo}

Cotrim Meirelles, Fernanda. A influência da Loja Conceito na percepção de marca e na atitude do consumidor. Caso Havaianas. Rio de Janeiro, 2019. 50 p. Trabalho de Conclusão de Curso - Departamento de Administração. Pontifícia Universidade Católica do Rio de Janeiro.

Empresas em todo o mundo têm utilizado lojas conceito como forma de reforçar os valores e a imagem da marca para os consumidores. O objetivo desta pesquisa é entender a percepção e atitude do consumidor sobre a marca a partir de lojas conceito e se os elementos utilizados na loja como cores, música, atendimento diferenciado e variedade de produtos ajudam a moldar a marca na mente dos consumidores. Como base teórica foram usados conceitos de branding, comportamento do consumidor, marketing de experiências e dados sobre a loja conceito e sua atmosfera de compras. Foi realizada uma pesquisa exploratória, com base na loja conceito da marca Havaianas, localizada no Rio de Janeiro. Os respondentes foram entrevistados logo após a sua visita à loja, compartilhando a imagem que já possuíam sobre a marca e as mudanças na sua percepção após a visita. Os dados foram analisados e interpretados e com base nisso, o trabalho propõe que marcas invistam em lojas conceito e em diferentes propostas para o ambiente varejista, buscando oferecer aos consumidores experiências diferenciadas que estimules os sentidos, criando memórias de longo prazo e conexões com a marca e seus valores.

Palavras- chave: Branding, Marketing de Experiência, Ambiente Varejista Lojas Conceito.

\section{Abstract}

Cotrim Meirelles, Fernanda. The Influence of Concept Stores on consumer brand perception and attitude; Havaianas' Case. Rio de Janeiro, 20019, 50 p. Course Completion Work - Administration Department. Pontifical Catholic University of Rio de Janeiro.

Companies all over the world has been using concept stores as a way to fortify their values and the brands image to the customers. The goal of this research is to understand the consumer brand perception and attitude from concept stores and if the elements used in those stores, such as colors, music, special service and product variety helps to shape the brand into consumer's minds. As theoretical basis were used branding concepts, consumer behavior, experience marketing and information about concept stores and it's shopping 
atmosphere. It was made an exploratory research, based on Havaianas' brand concept store, located in Rio de Janeiro. The respondents were interviewed right after their visit to the concept store, when they shared the brand's image they already had and what changed in their perception after visiting the concept store. The data was analyzed and interpreted, and based on the results, this study recommends that brands invest in concept stores and in different approaches for retail, pursuing to offer the customers new experiences that stimulate the senses, creating long term memories and connecting to the brand and it's values.

Palavras- chave: Branding, Experience Marketing, Retail Environment, Concept Stores. 


\section{Sumário}

1. Introdução 1

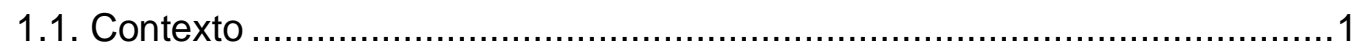

1.2. Objetivo Final.................................................................................

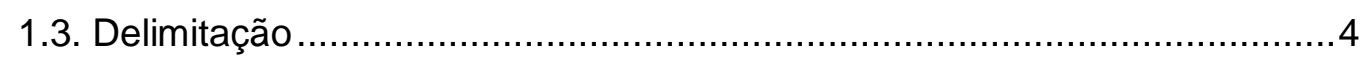

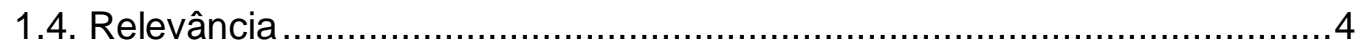

2. Referencial Teórico 6

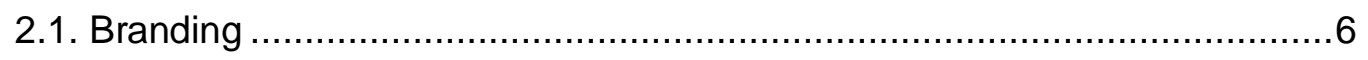

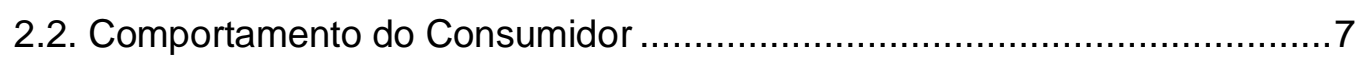

2.3. Marketing de Experiências............................................................. 10

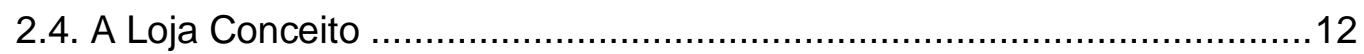

$\begin{array}{ll}3 . \text { Metodologia } & 17\end{array}$

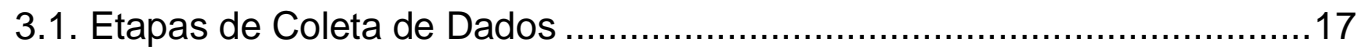

3.2. Fontes de Informação Selecionadas .................................................. 18

3.3. Procedimento e Tratamento dos Dados Coletados ...............................18

3.4. Limitações do Estudo..................................................................... 18

4. Apresentação e Análise de Resultados 20

4.1. Análise do perfil dos entrevistados.....................................................20

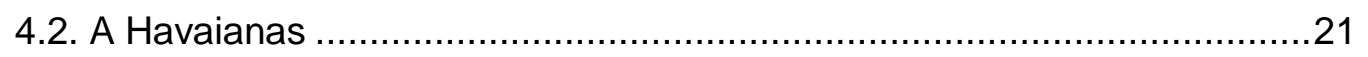

4.3. Análise da percepção dos entrevistados sobre a marca Havaianas.........25

4.3.1. Percepção antes da visita à loja conceito 25

4.3.2. Percepção após a visita à loja conceito 27

4.4. Análise da percepção do consumidor sobre o ponto de venda ................29

4.5. Análise do entendimento do consumidor sobre lojas conceito ..................31

4.6. Análise da experiência do consumidor na loja conceito ............................33

4.6.1. Instalações Exteriores 33

4.6.2. Interior da Loja 34

4.6.3. Disposição da Loja e Expositores Internos 36

4.6.4. Dimensões Sociais $\quad 37$

$\begin{array}{ll}\text { 4.6.5. Ambiente Holístico } & 37\end{array}$

5. Conclusões e recomendações para novos estudos 39 


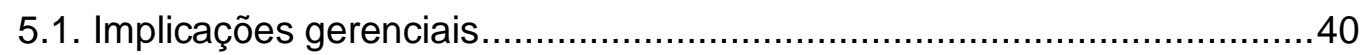

5.2. Recomendações para novos estudos .............................................. 41

6. Referências Bibliográficas 42

$\begin{array}{ll}\text { Anexo } 1 & 44\end{array}$

\section{Lista de Figuras}

Figura 1 - Modelo do comportamento do consumidor....................................... 9

Figura 2 - The Four Realms of an Experience .............................................. 11

Figura 3 - Sobre a Havainas.................................................................... 21

Figura 4 - Loja conceito da marca Havaianas em São Paulo ........................... 22

Figura 5 - Havaianas inaugura loja conceito no Rio de Janeiro ........................ 23

Figura 6 - Espaço Havaianas Rio .............................................................. 24

Figura 7 - Festa de inauguração do Espaço Havaianas Rio ............................. 25

\section{Lista de Tabelas}

Tabela 1 - Perfil dos Respondentes da Entrevista...................................... 20 


\section{Introdução}

\subsection{Contexto}

O conceito de vender experiências tem se expandido para além dos cinemas e parques de diversão e se tornado parte da estratégia de marketing de muitas marcas. A partir do momento em que uma marca busca despertar experiências em seus consumidores, seus produtos se tornam um diferencial, com apelos à memória, criando sensações marcantes, com tendência a permanecerem mais tempo na mente do cliente. (PINE e GILMORE, 2011).

Para o Marketing de Experiências, o valor não está apenas no produto ou no serviço, mas principalmente no momento da compra. A experiência deve ser construída pela marca de forma integrada: na loja, nos meios digitais e nas propagandas, para que a identidade da marca esteja sempre alinhada com a experiência a ser passada. (SCHMITT, 2011).

Para criar valor na mente do consumidor, é preciso ter uma imagem clara e coerente, com o suporte de um conjunto autêntico de diferenciação. Por isso, a marca tem tido cada vez mais participação na estratégia das empresas, sendo mais do que é um nome, um logotipo e um slogan, mas sendo a representação da experiência total que a empresa proporciona aos seus clientes. Por isso, as marcas têm frequentemente adotado "qualidades humanas" em seu posicionamento, buscando ser "fisicamente atraentes, intelectualmente interessantes, socialmente envolventes e emocionalmente fascinantes, ao mesmo tempo que devem demonstrar personalidade forte e moralidade sólida", expressando assim, as necessidades e desejos de seus consumidores. (KOTLER et al., 2017, p.143).

Para muitas categorias de produtos, os jovens muitas vezes são adotantes iniciais e estão prontos para influenciar o mercado. São definidores de tendências e agentes de mudanças, reagindo cada vez mais rápido e instantaneamente as mudanças que estão acontecendo no mundo. "A verdade é que a juventude simplesmente não tem medo de experimentar. Ela testa produtos novos e experimenta serviços inovadores que os segmentos mais velhos considerariam arriscados demais.”. (KOTLER et al., 2017, p.50).

Em seu livro "Vamos às Compras!", Paco Underhill (UNDERHILL, 2009) apresenta o shopper sensorial, revelando um consumidor que está cada vez mais interessado em experimentar os produtos e ter participação na hora da compra, interagindo e entrando em contato com a marca. 


\begin{abstract}
Grande parte da nossa experiência pioneira das coisas do mundo advém das compras. A que lugar vamos com a intenção específica de examinar objetos? Aos museus, é claro, mas ai de quem tocar em algo fora da lojinha de lembranças, um ambiente varejista. Somente lojas são plenas de oportunidades de exploração tátil e sensorial. Mesmo que não precisássemos comprar coisas, precisaríamos sair de casa para tocá-las e prová-las de vez em quando. (UNDERHILL, 2009, p.190)
\end{abstract}

Assim, as lojas conceito têm criado um ambiente de aproximação entre a marca e o cliente, sendo uma nova tendência no mercado contemporâneo, adotando recursos visuais e explorando aspectos emocionais e sensoriais. Arquitetura, localização, design, iluminação, cheiro, música, posicionamento dos produtos e o atendimento são diferenciais para que o público seja recebido com autenticidade e criatividade em um momento único. (SEBRAE, 2015).

\footnotetext{
Nos últimos anos, muitas grifes multinacionais investiram em lojas conceito. Essa tendência chega ao Brasil para atender uma nova classe consumidora, que mudou hábitos de compras, tornando-se mais exigente quando se trata de qualidade de produto e serviço. (SEBRAE, 2015, p.2).
}

No Relatório de Inteligência da SEBRAE sobre Calçados Femininos (2015) são trazidos exemplos de lojas conceito no Brasil das marcas Schutz, Melissa e Havaianas. A loja conceito da marca Schutz fica no Shopping Pátio Higienópolis, em São Paulo, sendo um projeto arquitetônico inovador, com estilo clean e tecnológico. O espaço conta com um grande video wall ocupando uma parede inteira, exibindo as campanhas e projetos da marca. A loja conceito da marca Melissa, localizada na Rua Oscar Freire, também em São Paulo, foi criada para ser um misto de loja e galeria de arte, sendo denominada Galeria Melissa. A proposta da loja é ser um canal de comunicação que reúne diferentes inspirações e desejos, relacionando a marca à arte, moda e design. Já a loja conceito da marca Havaianas, situada também na Rua Oscar Freire, em São Paulo, oferece os modelos tradicionais, além de bolsas, toalhas, e sandálias personalizadas. O projeto arquitetônico foi desenvolvido para criar um sistema de setorização e apresentação de produtos, de modo que os espaços foram transformados com diferentes temas e formas geométricas. 
A Havaianas é um caso em que o produto pelo seu apelo funcional não é suficiente para tornar a marca desejada. Isso faz com que a sua estratégia de comunicação seja baseada na emoção e no seu valor cultural, trazendo na comunicação slogans como "as legítimas" e "todo mundo usa", visando se fortalecer no mercado como a marca oficial de chinelos do país e construindo na mente do consumidor a ideia de que qualquer um pode usar Havaianas em diversos contextos. Assim, ao longo dos anos a marca ampliou seu alcance de uma personalidade popular para uma aceitação universal, estando presente tanto em bancas de jornal, quanto em lojas ícone, como as Galéries Lafayette em Paris. (BH1, 2018).

A Havaianas inaugurou a sua $2^{\text {a }}$ loja conceito no Brasil em 2018, em Ipanema, no Rio de Janeiro. O interior da loja é composto por sandálias Havaianas em seu modelo clássico de diversas cores, servindo como um papel de parede que pode ser visto de todos os cantos da loja, criando uma sensação de imersão e acolhimento. A identidade visual do espaço foi cuidadosamente projetada para carregar consigo o jeito leve e contemporâneo do carioca, buscando também retratar a Havaianas como símbolo do espírito brasileiro em todo o mundo. (ALMAP BBDO, 2018).

\footnotetext{
Quisemos proporcionar ao consumidor do Rio a oportunidade de vivenciar uma experiência sensorial da marca e retribuir 0 amor do carioca pela Havaianas", disse Carla Schmitzberger, vice-presidente global de sandálias, na inauguração da loja. $O$ prédio projetado pelo arquiteto Isay Weinfeld remete a uma "caixa preta" em que por dentro encontra-se um jardim tropical. (ROCHA e DURANTE, 2018, on-line).
}

Considerando o contexto abordado, este estudo tem como objetivo final avaliar a percepção e a atitude dos consumidores sobre a marca Havaianas a partir das experiências oferecidas pela loja conceito da marca em Ipanema, no Rio de Janeiro.

\subsection{Objetivos Intermediários}

Para isso, este estudo prevê como objetivos intermediários:

- Compreender se a loja conceito oferece ao consumidor uma experiência positiva de compra com relação ao espaço, atendimento, mobilidade, estética e opções de produtos. 
- Compreender se a loja conceito apresenta estímulos sensoriais que possam ser associados à imagem da marca, como cores, odores e música.

- Compreender se o consumidor entende esses estímulos e os associa de forma positiva à marca Havaianas, de modo que a loja conceito influencie na forma como o consumidor se identifica com a marca e seus valores.

\subsection{Delimitação}

Este estudo tem como objetivo final avaliar a percepção e atitude dos consumidores sobre a marca Havaianas a partir das experiências oferecidas pela loja conceito da marca em Ipanema, no Rio de Janeiro.

Este estudo não pretende mensurar os resultados financeiros da Havaianas com a loja conceito e nem proporcionar resultados quantitativos que comprovem a eficiência da loja conceito para a marca.

\subsection{Relevância}

A evolução para o Marketing 3.0 apresenta uma necessidade dos consumidores de interagirem com as marcas, humanizando as relações entre pessoas e organizações, de modo que os produtos não são mais vistos como uma solução cotidiana, mas sim como novas experiências que toquem o lado espiritual do consumidor. (KOTLER et al., 2010).

Por isso, cada vez mais as marcas têm adotado estratégias que permitam passar a sua mensagem e estar presentes nas mentes do consumidor de forma impactante. As lojas conceito então surgem como uma forma diferenciada de causar esse impacto e reforçar a imagem da marca para o consumidor. (O NEGÓCIO DO VAREJO, 2014).

Assim, esse estudo é relevante para o meio acadêmico, por associar os conceitos de marketing como Branding, Comportamento do Consumidor e Marketing de Experiências às lojas conceito, buscando entender como esses elementos interagem em uma aplicação prática.

O estudo também é relevante para empresas, pois a partir dos resultados é possível entender o que de fato chama a atenção do consumidor de forma positiva no momento da compra, tendo como base de estudo a marca Havaianas que possui valores fortes e bem construídos no mercado brasileiro e na mente do consumidor. É possível entender também como os consumidores percebem 
os elementos sensoriais nas lojas conceito, e como esses elementos podem ser usados para reforçar a conexão com a marca. 


\section{Referencial Teórico}

Neste tópico são apresentados e discutidos aspectos conceituais e estudos relacionados ao tema, que servem de base para a análise realizada. Esta seção está dividida entre conceitos de Branding, Comportamento do Consumidor, Marketing de Experiências e as Lojas Conceito para contextualizar o problema de estudo. Branding mostra a transformação do marketing tradicional, voltado para o produto, para o marketing relacionado à marca e seus valores que vão além das utilidades básicas. O Comportamento do Consumidor é relevante para a compreensão das diferentes formas de compra, entendendo como funciona o processo de decisão do consumidor e como as marcas podem atuar em cima desses comportamentos. O Marketing de Experiências exemplifica a atuação da marca, que através dos sentimentos, sentidos, sensações consegue engajar e estabelecer uma conexão marcante com o consumidor. Por fim, a Loja Conceito integra os sentidos ao processo de compra, buscando criar uma atmosfera holística que envolva o consumidor na imagem e nos valores da marca.

\subsection{Branding}

O marketing tradicional fazia uso de métodos analíticos, quantitativos e verbais para limitar a categoria dos produtos e seus concorrentes, buscando atribuir características e benefícios aos seus produtos para que os consumidores realizassem a compra com decisões racionais, ou seja, os produtos eram desenvolvidos para serem comprados por suas características e utilidades básicas, cumprindo o seu propósito de atender a necessidade do consumidor de forma objetiva. (SCHMITT, 1999).

O conceito de Branding surgiu para mudar essa estrutura, olhando para os produtos além de suas vantagens práticas, atribuindo a ele valores relacionados à marca, ao nome e ao logo. (SCHMITT, 1999).

Para Schmitt, a essência da marca é a sua rica fonte sensorial, de afeição e associações cognitivas que resultam em experiências memoráveis e recompensadoras. O consumidor busca produtos, comunicações, e campanhas que mexam com seus sentidos, com seus sentimentos, que estimulem suas mentes de um jeito que possam incorporar no seu estilo de vida. (SCHMITT, 1999). 
É comum que marcas adotem estratégias de curto prazo, como investimento em promoção de vendas. Para escapar disso as empresas devem buscar desenvolver a marca e seus conceitos, buscando se diferenciar do concorrente de forma sustentável. O conceito de brand equity (valor agregado ao produto ou serviço pela força e presença da marca) faz com que os consumidores se sintam parte da marca, gerando fidelização e agregando valor para o negócio. Brand awareness (consciência de marca), um dos pilares do brand equity, está associado a capacidade do consumidor de reconhecer 0 produto através da marca e se classifica em três níveis: reconhecimento de marca (o consumidor conhece a marca), recordação de marca (o consumidor associa o produto/serviço à marca) e Top of Mind (situação na qual uma marca é citada em primeiro lugar pelo consumidor, seja por preferência pelo produto oferecido, ou pela lembrança da marca). Para que a marca esteja presente na mente do consumidor é preciso ser diferente, memorável, utilizar slogans marcantes, criar uma memória visual com um logo facilmente reconhecível, investir em publicidade, patrocinar eventos que conectem a marca com o público alvo e considerar extensões da marca para outros produtos. (AAKER, 1991).

Outro pilar importante do brand equity são as associações de marca, que estão relacionadas a tudo o que a memória do consumidor associa a uma marca, sendo uma ligação que se estabelece através de experiências sensoriais ou por analogia a outras ligações. A partir dessas associações é formada a imagem da marca na mente do consumidor, sendo fundamental para a diferenciação do produto em relação à concorrência. (AAKER, 1991).

\subsection{Comportamento do Consumidor}

Para Solomon (2016), o ato de compras deixou de ser uma atividade voltada para o consumo de massa, em que todos os clientes buscam suprir a mesma necessidade, para se tornar uma cultura diversa, em que uma quantidade enorme de opções para os mais simples produtos é desenvolvida para agradar à todos os gostos.

Os estímulos de marketing, portanto, estão muito relacionados à cultura popular, músicas, filmes e celebridades, influenciando os gostos e as tendências da moda. A teoria dos papéis, mostra que cada consumidor se comporta como se fosse o protagonista de uma peça, podendo variar de papel dependendo do produto ou serviço a ser escolhido. Assim, as marcas podem estabelecer relacionamentos com seus clientes: ligação de autoconceito (ajudando a 
estabelecer a identidade do cliente), ligação nostálgica (servindo de "elo" com o passado), interdependência (parte da rotina diária) e amor (promovendo elos emocionais de afeto, paixão e outras emoções intensas). (SOLOMON, 2016).

Além disso, os consumidores possuem necessidades que servem de motivação na hora da compra, como: necessidade de afiliação (estar na companhia de outras pessoas), necessidade de poder (estar em controle do próprio ambiente) e necessidade de singularidade (afirmar sua identidade individual). (SOLOMON, 2016)

Para a psicologia do consumidor, o homem tem necessidades e desejos infinitos, precisando escolher diante de suas possibilidades finitas, como satisfazê-los da melhor forma, buscando minimizar seu sofrimento e maximizar seu prazer na hora da compra. O valor que cada ser humano atribui e reconhece em um produto ou serviço variam de acordo com a situação financeira do indivíduo, seus processos decisórios em torno da compra e aspectos psicológicos. (BLESSA, 2003).

O comportamento humano é motivado por suas necessidades básicas e é influenciado por seu meio social e suas memórias, onde estão armazenadas características pessoais, predisposições, informações, experiências, valores e atitudes. O comportamento do consumo acontece em seis etapas: reconhecimento do problema, processo decisório, procura de alternativas, avaliação das alternativas, compra e resultado da compra. As motivações de compra devem ser avaliadas considerando impulsos conscientes e inconscientes que levam à compra de um determinado produto no ponto de venda, sendo baseados principalmente em: hábitos, impulsos, motivação, conhecimento e pressão social. (BLESSA, 2003).

As compras muitas vezes são baseadas na emoção, no impulso, por isso, fazer com que o consumidor se sinta bem em relação à marca, trazendo uma emoção positiva é essencial. As emoções são divididas em primárias (alegria, tristeza, raiva, medo, surpresa, repulsa) e secundárias (amor, culpa, vergonha, orgulho, inveja e ciúme). Assim, a partir do amor, as marcas podem criar relacionamentos com seus consumidores que sejam mais emocionais e duradouros, estabelecendo conexões mais ricas e profundas. (ROBERTS, 2005).

O modelo do comportamento do consumidor se baseia em quatro fatores psicológicos principais que influenciam a reação do consumidor aos estímulos do marketing: motivação, percepção, aprendizagem e memória, como mostrado na figura abaixo. Os estímulos do marketing (produto, preço, distribuição e 
comunicação) associados aos estímulos ambientais (econômico, tecnológico, político e cultural), penetram o consciente do consumidor, de modo que os fatores psicológicos (motivação, percepção, aprendizagem e memória) combinados com as características do consumidor (culturais, sociais e pessoais) levam ao processo de decisão de compra e consequentemente a compra final. (LOKEN, 2006).

\section{Figura 1 - Modelo do comportamento do consumidor}

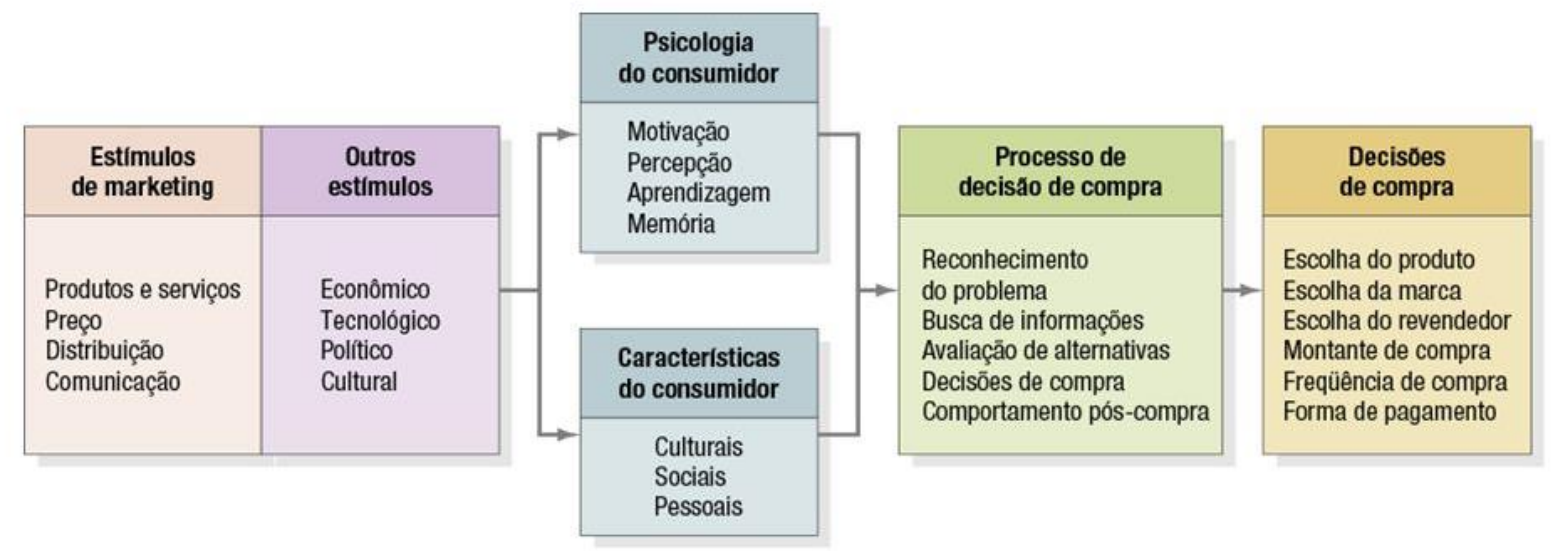

Fonte: KOTLER e KELLER, 2012, p. 172

A percepção é a forma que o indivíduo seleciona, organiza e interpreta as informações que recebe do mundo a sua volta, dependendo da relação entre suas condições internas e estímulos físicos com o ambiente. As pessoas podem ter diferentes percepções de uma mesma situação devido a três processos: atenção seletiva, distorção seletiva e retenção seletiva. A atenção seletiva filtra os estímulos que chegam ao indivíduo. A distorção seletiva é a tendência dos indivíduos de transformar a informação em significados pessoais e interpretá-la de modo que se encaixe nos nossos pré-julgamentos e expectativas. A retenção seletiva busca reter informações que confirmam nossas crenças e atitudes. (KOTLER e KELLER, 2012).

Relacionando percepção e marca, é importante saber que, devido à atenção seletiva, apenas algumas das comunicações vistas em um dia ficam de fato registradas na mente do consumidor. Assim, é preferencial utilizar estímulos relacionados a alguma necessidade atual, que os consumidores considerem previsíveis e que despertem desvios maiores do que o comum, como valores altos de desconto e promoções. Já a distorção seletiva impacta na absorção da informação passada ao consumidor, que pode eventualmente interpretar a comunicação de forma diferente ou inesperada pelo emissor. Além disso, a 
distorção seletiva faz com que os consumidores interpretem de forma diferente o produto dependendo da sua marca, associando uma melhor qualidade as marcas fortes. A retenção seletiva faz com que o consumidor retenha informações positivas sobre produtos que gosta, o que também costuma beneficiar marcas mais estruturadas e conhecidas. (KOTLER e KELLER, 2012).

No processo de compra, a atitude do consumidor atua principalmente na avaliação das alternativas de compra. As atitudes são adquiridas através das experiências e dos aprendizados de cada indivíduo, influenciando o seu comportamento de compra a partir de avaliações, sentimentos e tendências de ação em relação à objetos e ideias. (KOTLER e KELLER, 2012).

Dessa forma, as atitudes criam uma pré-disposição nas pessoas para gostarem ou não de um objeto, trazendo também coerência no comportamento em relação a objetos semelhantes. As atitudes poupam energia e reflexão para os consumidores e dificilmente mudam. Por isso, é importante que as marcas busquem adaptar seus produtos e valores considerando as atitudes preexistentes do seu público alvo. (KOTLER e KELLER, 2012).

\subsection{Marketing de Experiências}

O processo fundamental do marketing é o consumo, que está diretamente relacionado à satisfação, valor e utilidade. Consumir experiências tem se tornado uma nova parte do consumo na era digital. Todos os consumidores possuem experiências básicas que auxiliam na percepção dos sentidos, registrando e filtrando o que sentem e sabem sobre o mundo ao redor, definindo o que é bom ou ruim. (ACHROL e KOTLER, 2011).

Experiência, para Schimitt (1999), está relacionada aos acontecimentos individuais que ocorrem como resposta a um estímulo, gerando memórias que podem durar a vida toda. Normalmente são resultados de uma observação direta ou da participação nos acontecimentos, sejam esses reais, imaginários ou virtuais.

Para Pine e Gilmore (2011), experiências, assim como produtos e serviços, devem suprir a necessidade do consumidor, resultando em processos interativos de pesquisa, design, desenvolvimento, roteiros e encenação. A experiência como ferramenta de marketing serve de estratégia para envolver intencionalmente os consumidores. $O$ Marketing de Experiências cria associações sensoriais, afetivas e cognitivas dos consumidores com as marcas, gerando um diferencial competitivo significativo. 
As experiências podem ser classificas em quatro campos ou "reinos": Entretenimento, Educacional, Estética e Escapismo, como mostrado na figura a seguir. Observando o eixo horizontal, os reinos Entretenimento e Educacional criam uma relação de absorção, em que o indivíduo participa mentalmente, à distância, enquanto os reinos Estética e Escapismo atuam com imersão, com participação física ou virtual. Já observando o eixo vertical, nos reinos Entretenimento e Estética, o espectador não afeta ou influencia diretamente a experiência, enquanto nos reinos, Educacional e Escapismo, o espectador afeta a performance ou o evento que gera a experiência. O Marketing de Experiências pode atuar em qualquer um dos quatro reinos, podendo transitar entre eles e variar dependendo da atividade e da percepção do consumidor. (PINE e GILMORE, 2011).

Figura 2 - The Four Realms of an Experience

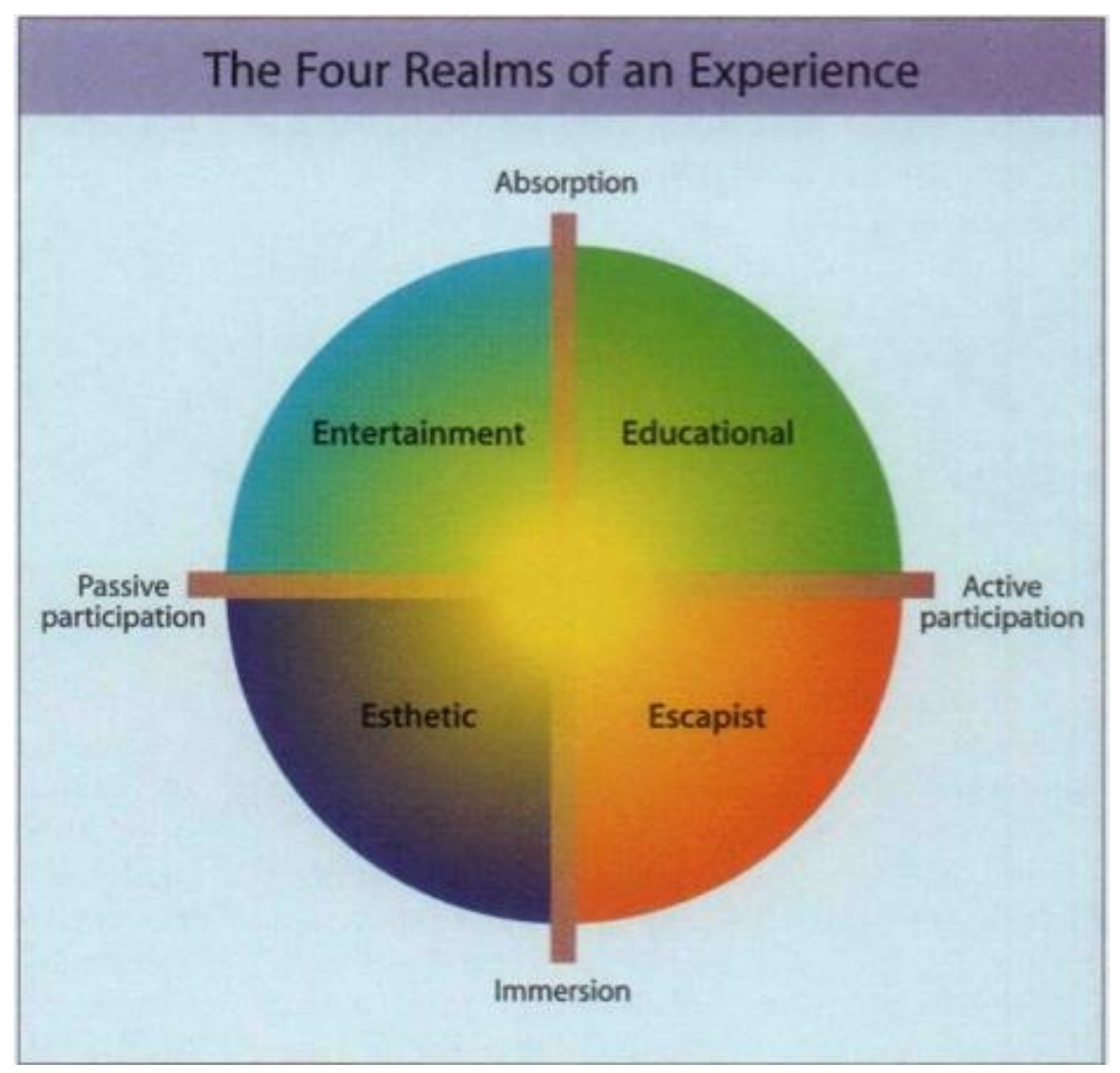

Fonte: PINE; GILMORE, 1998, p. 102

Para Schmitt (1999), existem quatro características primordiais do Marketing de Experiências: foco na experiência do consumidor, foco no consumo como experiência holística (parte do comportamento natural do ser humano), 
reconhecer os clientes como indivíduos racionais e emocionais e por fim, compreender que os métodos e ferramentas para implantar o marketing de experiências devem ser fora do padrão convencional.

Schmitt (1999) apresenta Módulos Estratégicos Experienciais que devem ser abordados no Marketing de Experiências: experiências sensoriais (sense), que exploram os cinco sentidos; experiências afetivas (feel), que despertam os sentimentos e emoções; experiências cognitivas criativas (think), que geram o diálogo entre diferentes ideias através de surpresas, intrigas e provocação; experiências físicas, de comportamento e estilo de vida (act), que abordam alternativas sobre o que é feito no dia a dia; e por fim, experiências de identidade social/cultural em relação ao grupo (relate), que engloba todos os outros quatro módulos, mas expande esses estímulos para o grupo. As experiências de marketing podem conter mais de um módulo, e quanto mais formas de se conectar com o consumidor, mais marcante será aquela experiência.

\subsection{A Loja Conceito}

Eventos e experiências são criados por marcas visando ampliar e aprofundar o relacionamento com o consumidor. As experiências passaram a ser criadas com produtos e marcas em ambientes internos e externos, como o $M \& M$ World na Times Square, em Nova Iorque, e o Everything Coca Cola em Las Vegas, criando uma "atmosfera", um ambiente calculado que cria ou reforça o desejo de compra do produto. (KOTLER e KELLER, 2012).

As lojas conceito costumam vender produtos de uma única marca, sendo uma loja própria desenvolvida com a intenção de construir ou reforçar a imagem da marca mais do que vender os produtos necessariamente. (KOZINETS et al., 2002).

Como principais características, as lojas conceito são localizadas em espaços movimentados pelas compras como ruas conhecidas e grandes galerias, contendo os principais produtos da marca em um ambiente de alta qualidade em termos de atendimento e design, comunicando o posicionamento e os valores da marca. Assim, a loja conceito pode atuar como estratégia de entrada da marca no mercado, além de servir como um bom instrumento para estabelecer relacionamentos, atraindo novos stakeholders. A loja também pode ampliar a comunicação da marca com eventos no espaço, como a própria inauguração da loja ou a promoção de um novo lançamento. Por fim, a loja conceito pode servir como uma loja modelo, onde a marca pode testar novos 
produtos, materiais diferenciados de ponto de venda e inovar no atendimento ao cliente, sendo então classificada como flagship store. (MANLOW e NOBBS, 2012).

As lojas conceito variam das lojas comuns do varejo pela sua escala, pelo design, localização, configuração do espaço e custos operacionais, tendo como principal função ser um mostruário da marca, dando suporte e reforçando as suas conexões no mercado. As lojas conceito costumam ter grandes estruturas como uma forma de mostrar o tamanho da marca (principalmente no mercado de luxo), além de oferecer um espaço amplo que permita a exposição de produtos variados e o movimento do consumidor na loja. Por isso, arquitetos famosos são envolvidos no projeto, buscando criar diferentes experiências em loja, com novas ideias de design para desenvolvimento do varejo. (MOORE et al., 2008).

A loja conceito está muito relacionada ao marketing sensorial, em que a experiência é gerada através das reações dos cinco sentidos aos estímulos sensoriais do ambiente como luz, cor, som, odores e texturas. Esses estímulos são captados pelos receptores sensoriais (olhos, ouvido, nariz, boca e pele), passando pelo processo de percepção em três etapas: exposição, atenção e interpretação. Cada indivíduo passa por um processo único de seleção de estímulos, identificando quais captam mais a sua atenção. (SOLOMON, 2016).

Criar uma "atmosfera de compras" refere-se ao design de um ambiente, através das comunicações visuais, iluminação, cores, música, aromas, que buscam resultar em respostas emocionais dos clientes afetando o seu comportamento de compra. As características da loja, desde a disposição dos produtos nas gôndolas, até o chão, as paredes, o ar condicionado e as pessoas presentes no ambiente contribuem para que o consumidor queira ou não comprar um produto. É importante considerar como o consumidor vê o ponto de venda, como se sente e como é atendido. (BLESSA, 2003).

Para Somolon (2011), a atmosfera da loja impacta diretamente na percepção que o consumidor tem sobre a marca. Lojas com personalidades marcantes como design, localização, adequação dos produtos, conhecimento do cliente e qualidade de equipe impactam na formação da imagem da marca na mente do consumidor e através de uma atmosfera de compras diferenciada os varejistas são capazes de despertar determinadas reações e estímulos positivos de seus consumidores.

Consumidores são seres humanos e com isso possuem sentidos que os alertam, provocam, advertem e trazem alegria. Visão, audição, olfato, tato e 
paladar agem juntos e trazem resultados inesquecíveis quando são estimulados ao mesmo tempo. Também deve-se considerar os sentidos vitais que captam a temperatura, iluminação, e o espaço ao redor. No final, as experiências associadas aos sentidos criam as memórias de longo prazo e perduram na mente do consumidor. (ROBERTS, 2005).

O servicescape ou "paisagem de serviço" é um conceito fundamental da experiência de serviços. Os parques da Disney são exemplos de como fazer o cliente se sentir à vontade e satisfeito com o que é oferecido, garantindo uma memória positiva de longo prazo. O servicescape seria referente à toda a parte visível do serviço, incluindo decoração, iluminação, aroma, arquitetura, vitrine, temperatura. Com isso, empresas podem oferecer ambientes estimulantes visando tanto projetar as experiências dos clientes e moldar seu comportamento, quanto transmitir a imagem planejada da marca e fortalecer seu posicionamento e estratégias de diferenciação. (LOVELOCK et al., 2011).

A interação do ambiente com o cliente contribui em grande parte para uma experiência memorável por estimular sensações, sentimentos e emoções. Para Lovelock et al. (2011), os estímulos no ambiente são processados pelos cinco sentidos, gerando as sensações. A partir dessas sensações, processos cognitivos e psicológicos criam conhecimentos e sentimentos, tanto racionais quanto emocionais. As emoções representam uma experiência afetiva mais intensa, como alegria e tristeza, que costumam despertar reações físicas como o choro, a risada e o aumento dos batimentos cardíacos.

De acordo com o modelo de paisagem de serviço de Mary Jo Bitner (1992), existem três dimensões ambientais: condições do ambiente; espaço e função; sinais, símbolos e artefatos. As condições do ambiente seriam temperatura, qualidade do ar, sons e aromas, enquanto o espaço e a função estão mais associados à layout, equipamentos utilizados e mobiliário. Os sinais, símbolos e artefatos são as sinalizações do espaço, os objetos e o estilo da decoração. Todos esses elementos fazem parte do Ambiente Holístico, em que os funcionários e os clientes interagem, cada um com suas respostas internas cognitivas (crenças e percepções de qualidade), emocionais (sentimentos e estados de ânimo) e psicológicas (dor e conforto). A partir dessa interação social são gerados diferentes comportamentos, que podem ser positivos ou negativos, como atração ou afastamento. (LOVELOCK et al., 2011).

Quando se trata de lojas varejistas, existem dimensões e elementos que ajudam na construção de um ambiente ideal para entreter o cliente. Nas Instalações Exteriores é importante ter um estilo arquitetônico com uma fachada 
atraente que gere visibilidade para a loja. É preciso considerar a localização, o que está ao redor, se o deslocamento e o acesso são fáceis. Para o Interior da Loja é preciso considerar desde esquemas de cor, iluminação, aromas, sons e música, acessórios e texturas nas paredes, até a composição do teto, temperatura do ambiente, limpeza, disposição e organização dos provadores e os acessos através de elevadores ou escadas. (LOVELOCK et al., 2011).

Outra dimensão é a Disposição da Loja, que deve considerar o posicionamento dos produtos, a localização do caixa, as áreas de fluxo e as possíveis filas. Expositores Internos fazem parte de outra dimensão, que engloba os pôsteres, placas e cartões expostos na loja, as figuras e elementos gráficos, os efeitos para a tematização do ambiente, a forma como os produtos estão expostos e os preços, assim como estantes e caixas. Por fim, a quinta dimensão é a das Dimensões Sociais, que traz para o ambiente varejista as características pessoais, dos funcionários e dos clientes, a forma de interação, o uniforme dos atendentes, a privacidade e o autosserviço. (LOVELOCK et al., 2011).

A música, mesmo em volumes baixos pode gerar impacto na percepção e comportamento do consumidor no ambiente. $O$ ritmo, o volume e a harmonia são percebidos de maneira holística e diferenciada de acordo com as características do ouvinte. A música é capaz de ajustar a velocidade com que os clientes interagem com o ambiente. Restaurantes podem ajustar a trilha sonora para um ritmo mais rápido se quiserem uma rotatividade maior nas mesas, ou optar por um ritmo mais lento se quiserem aumentar o rendimento com as bebidas. A música também tem o poder de encurtar o tempo de espera percebido em filas e ajuda a filtrar o público alvo desejado pela loja. (LOVELOCK et al., 2011).

Os odores, cheiros, aromas, muitas vezes podem passar despercebidos pelo cliente, mas pode gerar um forte impacto no estado de ânimo, nas respostas emocionais, no comportamento e nas intenções de compra do consumidor na loja. De acordo com a aromaterapia, os aromas podem ser utilizados para despertar reações fisiológicas, comportamentais e emocionais. Eucalipto é uma fragrância estimulante e energizante, enquanto lavanda é mais calmante e relaxante. Limão ajuda a equilibrar os níveis energéticos e pimenta do reino equilibra as emoções. (LOVELOCK et al., 2011).

Assim como os aromas, as cores também conseguem gerar efeitos impactantes sobre os sentimentos. As cores podem ser classificadas em três dimensões: Matiz é o pigmento da cor (cores quentes: vermelho, laranja, amarelo; cores frias: verde, azul ou violeta), valor é o grau de claro ou escuto, e 
croma é a intensidade, pigmentação, saturação. Cores mais cromadas são mais vívidas, enquanto cores menos cromadas são mais opacas. As cores quentes são associadas a estímulos, animação, alta energia, expressão, otimismo e paixão, enquanto cores frias são associadas a paz, calma, espiritualidade, serenidade, cura e amor. Em um ambiente varejista, cores quentes incentivam decisões rápidas, por impulso, enquanto cores frias podem ajudar em uma compra de alto envolvimento. (LOVELOCK et al., 2011).

A combinação de todos os fatores mencionados cria uma visão holística, em que todas as dimensões do projeto são otimizadas simultaneamente, agindo de forma integrada para gerar a melhor experiência para o consumidor. "A característica holística transforma o projeto de ambientes de serviços em arte". Com isso, percebe-se que o ambiente age diretamente na modelagem da percepção do consumidor sobre a imagem e posicionamento de uma marca, fazendo com que os clientes se sintam bem e satisfeitos. (LOVELOCK et al., 2011). 


\section{Metodologia}

Este capítulo pretende apresentar a metodologia utilizada para esse estudo, incluindo as etapas de coleta de dados, tipo de pesquisa, escolha dos sujeitos entrevistados, forma de tratamento e análise das respostas e suas limitações.

Estudos de campo utilizam a pesquisa qualitativa, se diferenciando das análises de dados em pesquisas experimentais e levantamentos que analisam de forma quantitativa. Para a análise dos dados de forma qualitativa são utilizadas três etapas: redução, exibição e conclusão/verificação. A redução consiste no processo de seleção e simplificação dos dados, determinando a forma de agrupar as informações e codificar as categorias, tornando mais simples a construção e verificação das conclusões. Já na exibição, os dados selecionados devem ser organizados para possibilitar análises sistemáticas de suas principais diferenças A terceira etapa, conclusão/verificação requer que os dados sejam revisados de modo a considerar da melhor forma seus significados, padrões e explicações. (GIL, 2008).

\subsection{Etapas de Coleta de Dados}

A coleta de dados foi feita com natureza exploratória, tendo o objetivo de desenvolver, esclarecer e modificar conceitos e ideias a partir de hipóteses pesquisáveis. A pesquisa foi um estudo de campo, sendo de cunho qualitativo.

Foram realizadas entrevistas com frequentadores da loja conceito da marca Havaianas no Rio de Janeiro em agosto e setembro de 2019.

A primeira etapa do estudo constituiu em comparecer à loja conceito da marca Havaianas e buscar entender como os elementos citados nas teorias envolvendo as lojas conceito poderiam ser identificados e compreendidos.

A segunda etapa englobou as entrevistas presenciais, realizadas com frequentadores da loja logo após terem realizado a visita. Foram realizadas entrevistas individuais, em pares e em grupos, dependendo de como os entrevistados se sentiam mais confortáveis de responder as perguntas e de como os mesmos visitaram a loja.

A entrevista é uma técnica muito usada no âmbito das ciências sociais para a obtenção de dados que interessam a um determinado estudo. É uma forma de interação social. As entrevistas fornecem informações sobre o que as 
pessoas sabem, acreditam, esperam, sentem e desejam, sendo muito eficientes para a obtenção de dados sobre o comportamento humano. (GIL, 2008).

\subsection{Fontes de Informação Selecionadas}

Inicialmente o estudo se baseou em dados secundários sobre a marca Havaianas, com base principalmente o site da marca, no site da agência AlmapBBDO, que realizou a concepção das lojas conceito, e da plataforma BH1 que disponibiliza artigos sobre marketing, gerenciamento e tecnologia.

Foi realizada a coleta de dados primários, obtidos diretamente dos entrevistados. O principal critério para a escolha foi a visita à loja conceito da marca Havaianas, sendo consumidores brasileiros tendo uma faixa etária de 20 a 70 anos.

O objetivo principal foi compreender como os consumidores percebem os elementos da loja conceito e como isso influencia a percepção sobre a marca Havaianas. Foram realizadas 15 entrevistas presenciais, algumas em dupla e em grupo (22 respondentes no total), considerando os critérios acessibilidade e conveniência.

\subsection{Procedimento e Tratamento dos Dados Coletados}

A coleta de dados foi feita com os consumidores logo após a sua visita à loja conceito e o tempo de cada entrevista variou dependendo da disponibilidade do entrevistado e do seu engajamento com as perguntas.

Foram ao todo 18 perguntas (Anexo 1) em um roteiro semiestruturado. $O$ instrumento utilizado para registar os dados foi o gravador do aparelho celular para registro das respostas. Após a coleta dos dados, as respostas das entrevistas foram organizadas e categorizadas, dando destaque para os principais pontos constatados. Por fim, os dados foram analisados e interpretados, buscando cumprir o objetivo proposto pelo estudo.

\subsection{Limitações do Estudo}

De acordo com Gil (2008), são limitações comuns nas entrevistas: falta de motivação dos entrevistados, possível compreensão inadequada das perguntas, inabilidade do entrevistado de responder adequadamente alguma pergunta e a influência exercida pelo entrevistador sobre o entrevistado pelo aspecto social e opiniões pessoais. 
Além disso, é importante destacar como limitações do estudo a associação do entrevistador à marca Havaianas, pela localização próxima a loja conceito no momento das perguntas. Este fator pode ter enviesado as respostas a serem mais positivas. Além disso, o engajamento dos entrevistados variou bastante, muito associado ao interesse pela marca e pela loja conceito. 


\section{Apresentação e Análise de Resultados}

\subsection{Análise do perfil dos entrevistados}

Os entrevistados foram abordados após a sua visita à loja conceito. Foram escolhidos brasileiros, homens ou mulheres, na faixa etária de 20 a 70 anos. As entrevistas realizadas em duplas ou em grupos foram consideradas como uma única entrevista, diante das respostas compartilhadas e discutidas pelos participantes.

Tabela 1 - Perfil dos Respondentes da Entrevista

\begin{tabular}{|c|c|c|c|}
\hline № da Entrevista/Formato & Gênero & Idade & Cidade/Bairro/Estado de Moradia \\
\hline \multirow{2}{*}{1 - Dupla } & Feminino & 24 & Rio de Janeiro - Barra da Tijuca \\
\hline & Feminino & 35 & Rio de Janeiro - Ipanema \\
\hline 2 - Individual & Masculino & 36 & Rio de Janeiro - Ipanema \\
\hline \multirow{2}{*}{3 - Dupla } & Feminino & 53 & São Paulo (SP) \\
\hline & Masculino & 56 & São Paulo (SP) \\
\hline 4 - Individual & Feminino & 65 & Rio de Janeiro - Ipanema \\
\hline \multirow{2}{*}{5 - Dupla } & Masculino & 27 & Rio de Janeiro - Copacabana \\
\hline & Masculino & 29 & Porto Alegre (RS) \\
\hline \multirow{3}{*}{6 - Trio } & Feminino & 25 & Brasília (DF) \\
\hline & Feminino & 25 & Brasília (DF) \\
\hline & Feminino & 24 & Brasília (DF) \\
\hline \multirow{2}{*}{7 - Dupla } & Feminino & 58 & Rio de Janeiro - Ipanema \\
\hline & Masculino & 63 & Rio de Janeiro - Ipanema \\
\hline 8 - Individual & Feminino & 24 & Rio de Janeiro - Leblon \\
\hline 9 - Individual & Feminino & 26 & Rio de Janeiro - Botafogo \\
\hline 10 - Individual & Feminino & 48 & Rio de Janeiro - Copacabana \\
\hline 11 - Individual & Masculino & 28 & Rio de Janeiro - Tijuca \\
\hline 12 - Individual & Feminino & 22 & Rio de Janeiro - Gávea \\
\hline 13 - Individual & Masculino & 24 & Rio de Janeiro - Barra da Tijuca \\
\hline 14 - Individual & Feminino & 24 & Rio de Janeiro - Botafogo \\
\hline \multirow{2}{*}{15 - Dupla } & Feminino & 23 & Rio de Janeiro - Copacabana \\
\hline & Masculino & 25 & Rio de Janeiro - Copacabana \\
\hline
\end{tabular}

Fonte: Pesquisa de Campo (2019) 


\subsection{A Havaianas}

As Havaianas foram criadas em 1960 inspiradas pelas sandálias japonesas Zori, feitas com palha de arroz e tiras de tecido. O nome foi inspirado no Havaí por ser o lugar dos sonhos nos anos 1960. Logo quando o produto foi lançado, as Havaianas foram vendidas por todo o país, conquistando rapidamente os trabalhadores em diversas cidades. Em 1966 a Alpargatas, grupo proprietário das Havaianas registrou a patente do chinelo de dedo de borracha que inicialmente era apenas produzido nas cores azul e branca. Acidentalmente, por um erro de fábrica foram produzidas sandálias verdes que acabaram indo para o mercado e sendo amadas imediatamente. Com o movimento Hippie ganhando cada vez mais força, as Havaianas logo entraram na moda dos jovens. Assim, surgiram os primeiros concorrentes e o famoso slogan “As Legítimas". Nos anos 1990, a marca descobriu não ser usada apenas por trabalhadores em todo o Brasil, mas também por famosos, passando a investir ainda mais em comunicação e inovação no design dos produtos, lançando sandálias com estampa floral e de cores variadas, também nos formatos kids e fit e reforçando a mensagem de que "Todo mundo usa". (HAVAIANAS, 2019).

Figura 3 - Sobre a Havainas

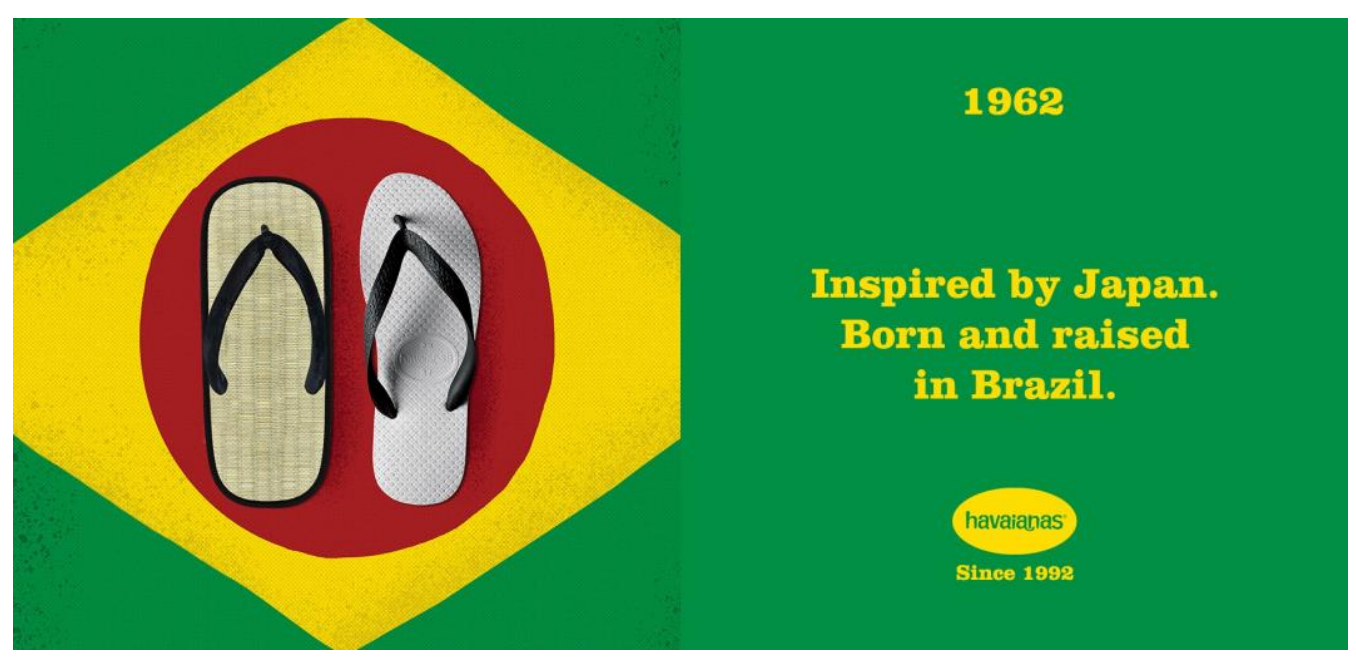

Fonte: Site da marca Havaianas ${ }^{1}$

1Disponível em: <https://www.havaianas-store.com/pt/historia>. Acesso 27 out. 2019. 
A partir dos anos 2000 a Havaianas já atuava em passarelas, acompanhando o sucesso de estilistas e grandes marcas brasileiras, estando presente em diversos países do mundo, como Espanha, Portugal, Itália, França, Japão, Estados Unidos e Inglaterra. As inovações e parcerias da Havaianas não pararam mais. Em 2009 a marca inaugura sua primeira loja conceito, o Espaço Havaianas localizado na Oscar Freire em São Paulo. A loja possui em seu centro uma banca de frutas buscando homenagear a origem popular da marca, além de contar com todos os modelos e cores dos produtos. (HAVAIANAS, 2019).

Figura 4 - Loja conceito da marca Havaianas em São Paulo

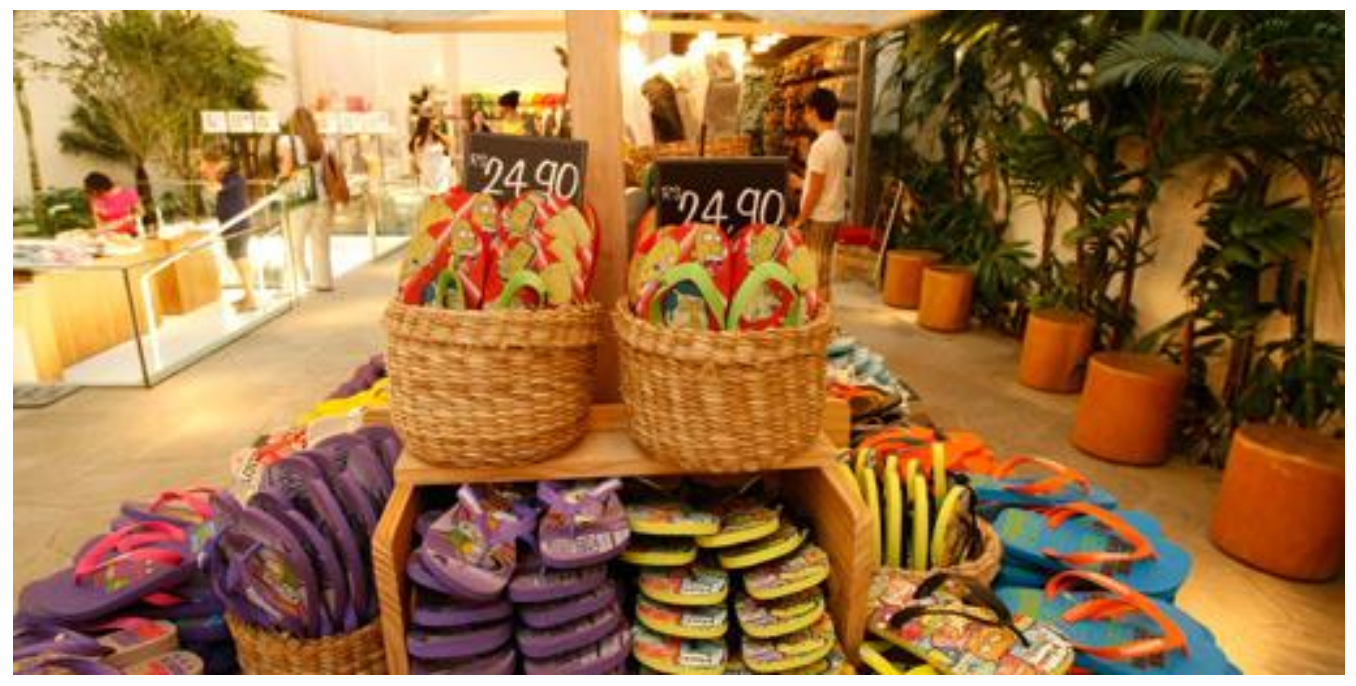

Fonte: Reportagem do site Diário do Comércio².

2Disponível em: <https://dcomercio.com.br/categoria/negocios/oscar-freire-troca-oluxo-por-comercio-democratico->. Acesso 27 out. 2019.

Assim, a Havaianas criou um brand equity baseado na emoção e nos valores culturais, acrescentando características brasileiras à marca como a irreverência, descontração, criatividade e diversidade. A associação da marca à Copa do Mundo de 1998 foi fundamental para tornar a marca um ícone da cultura brasileira internacionalmente. A partir de então, ações criativas, como a distribuição de chinelos personalizados para as celebridades indicadas ao Oscar em 2003 e ações em lançamentos de filmes de sucesso geraram para a Havaianas muita mídia espontânea e ajudaram a comunicar a marca para o mundo como um elemento cultural. O sucesso da marca no Brasil e no mundo comprovam a sua eficácia como transmissora dos valores da cultura brasileira, sendo um agente de construção e propagação dos mesmos por estarem ligados diretamente à essência da marca. (Machado, 2018) 
Em 2009, o Espaço Havaianas é aberto na rua Oscar Freire, em São Paulo. Trata-se de uma loja conceito, criada com o objetivo de oferecer toda a linha de produtos e de, principalmente, transmitir a essência ou "DNA" da marca: descontraída, criativa, brasileira e global. (Machado, 2018, on-line)

Em 2018, a Havaianas inaugurou sua segunda loja conceito, na Rua Garcia D'Avila em Ipanema no Rio de Janeiro. O Espaço Havaianas Rio foi projetado pelo arquiteto Isay Weinfeld em parceria com a agência AlmapBBDO para ser um espaço que oferece interatividade e diversas sensações ao público. A fachada da loja é inteiramente escura, remetendo a uma misteriosa caixa preta e ao entrar na loja é possível sentir a atmosfera solar e descontraída. Os três andares da loja são interligados por um enorme painel feito com as sandálias Havaianas de todas as cores. A identidade visual do espaço foi baseada no jeito leve e contemporâneo do carioca, desde as sacolas até os provadores, reforçando a imagem do Rio de Janeiro como a cidade do "verão brasileiro" para o mercado exterior e buscando retratar o espírito brasileiro que a Havaianas representa. "Quisemos proporcionar ao consumidor do Rio a oportunidade de vivenciar uma experiência sensorial da marca e retribuir o amor do carioca por Havaianas", comentou Carla Schmitzberger, vice-presidente Global de Sandálias. (ALMAP BBDO, 2018, on-line).

Figura 5 - Havaianas inaugura loja conceito no Rio de Janeiro

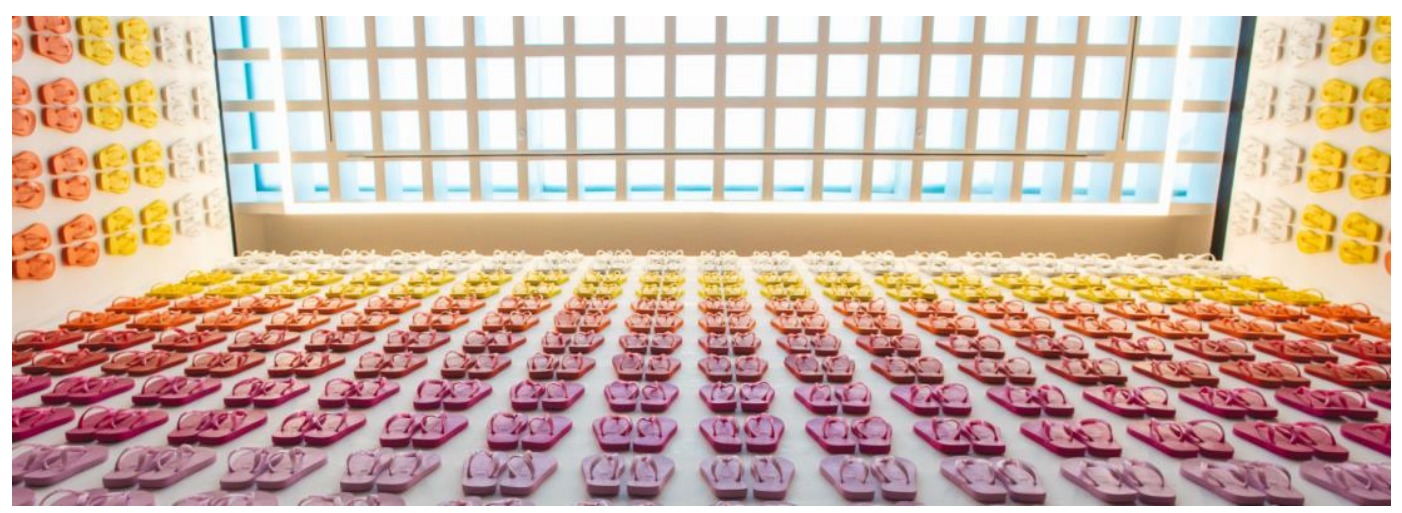

Fonte: Site da agência de publicidade Almapbbdo ${ }^{4}$.

${ }^{4}$ Disponível em: <https://www.almapbbdo.com.br/pt/trabalhos/havaianas-inauguraloja-conceito-no-rio-de-janeiro+285>. Acesso 27 out. 2019. 
Figura 6 - Espaço Havaianas Rio

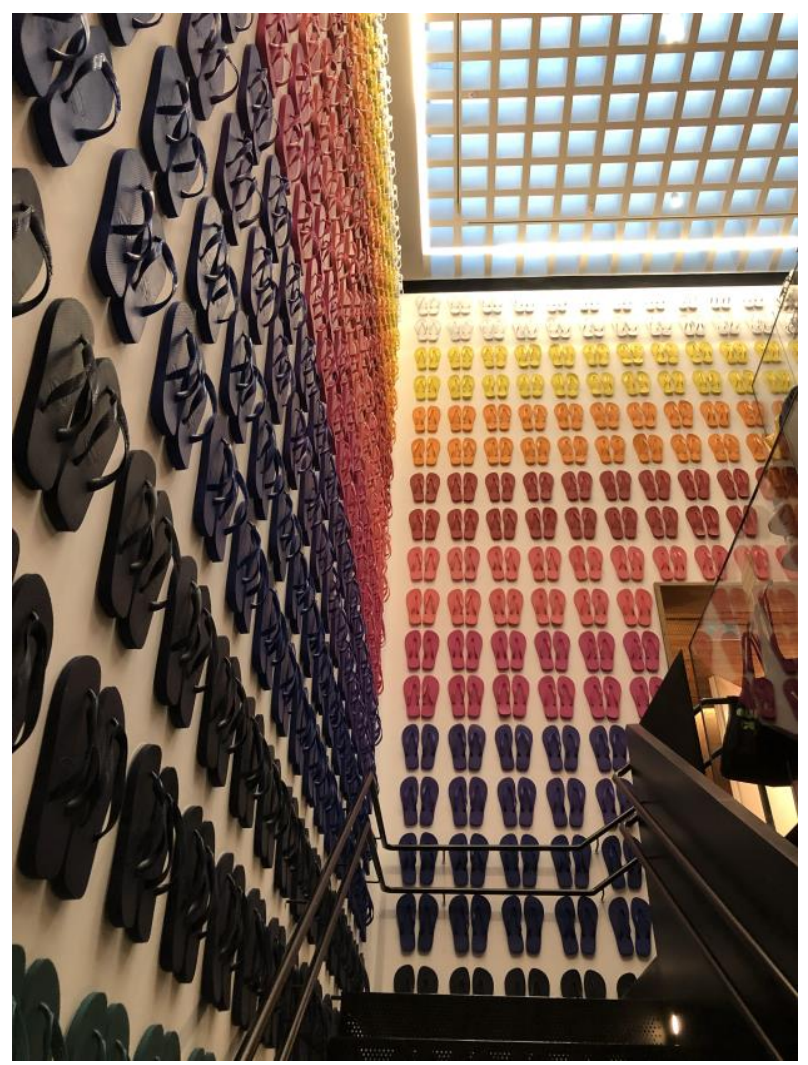

Fonte: Acervo pessoal do autor (2019).

O evento de inauguração do Espaço Havaianas Rio foi realizado com a presença celebridades que compartilharam o evento em tempo real nas redes sociais, além de shows que agitaram o público de moradores locais, fãs da marca, visitantes, influenciadores e artistas. O evento contou com projeções visuais na fachada da loja e apresentações de dança nos ritmos cariocas: samba, funk e bossa nova. Tudo isso para "marcar a chegada de um novo ponto turístico para os apaixonados pelo Rio de Janeiro". (ALMAP BBDO, 2018, online). 
Figura 7 - Festa de inauguração do Espaço Havaianas Rio

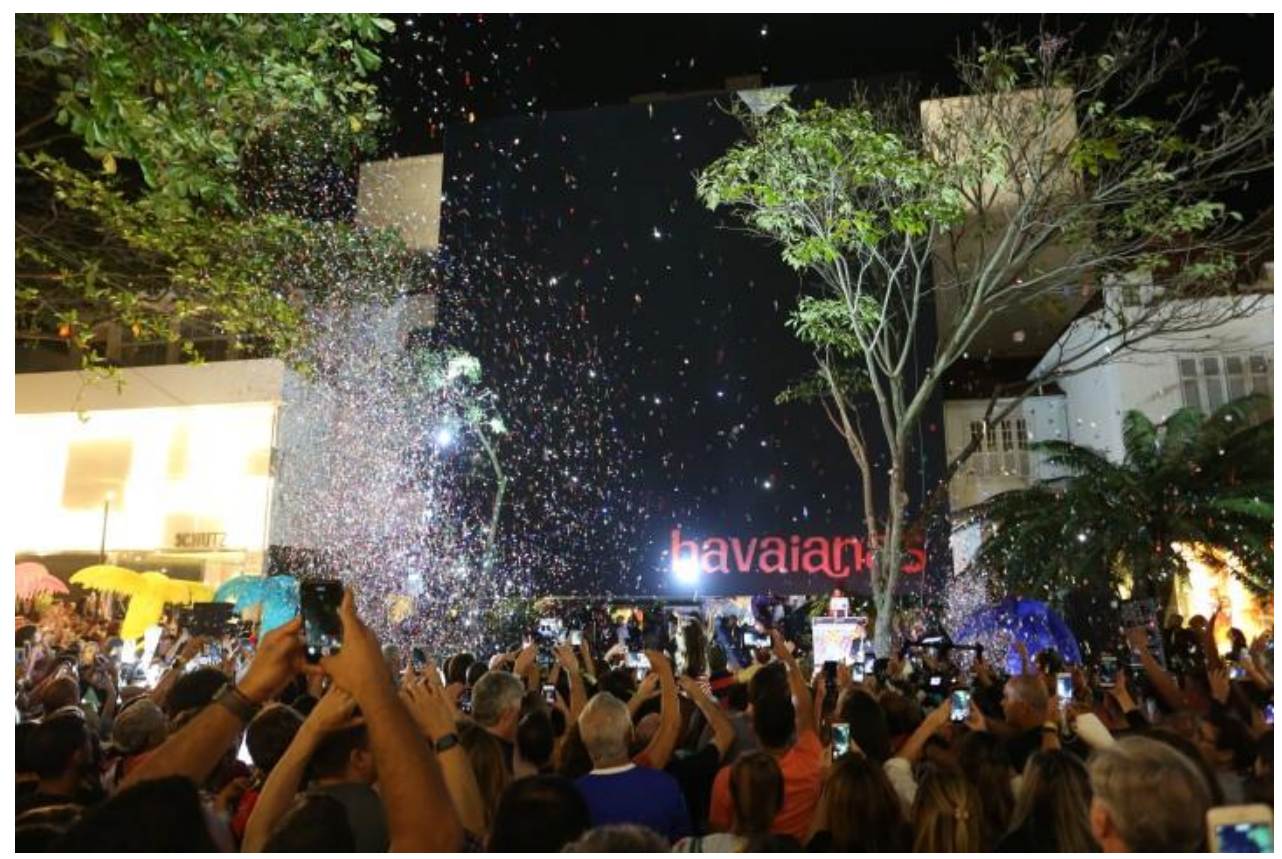

Fonte: Site Vipado 5 .

${ }^{5}$ Disponível em: <http://www.vipado.com.br/vipados-marcam-presenca-nainauguracao-do-espaco-havaianas-no-rio-de-janeiro/>. Acesso 27 out. 2019.

\subsection{Análise da percepção e atitude dos entrevistados sobre a marca Havaianas}

\subsubsection{Percepção e atitude antes da visita à loja conceito}

A primeira pergunta da entrevista convida os respondentes a relembrarem o seu primeiro contato com a marca Havaianas, também abordando se já conheciam a marca e se já possuíam algum produto. A segunda pergunta pede para que o entrevistado descreva a Havaianas como marca enquanto a terceira pergunta já aborda a identificação desse consumidor com a marca e os produtos.

Todos os entrevistados conheciam a marca Havaianas antes da visita à loja conceito. A grande maioria não se lembra da primeira vez que teve contato com a marca, os mais velhos dizendo por ter sido muitos anos antes e os mais jovens por usarem o chinelo da Havaianas desde muito pequenos. 
"B: Conheço desde que fundaram. A: Sim, conheço a marca desde a minha infância. A primeira vez que usei eu tinha uns 8 anos. $B$ : As minhas eram brancas e azuis! A: E as minhas brancas e amarelas!" (Entrevista 3)

"Tive contato desde que era criança e usava Havaianas para ir pra praia. Minha mãe comprou minha primeira sandália." (Entrevista 1)

A grande maioria também relatou já terem produtos da marca, principalmente os clássicos chinelos de dedo que já usam há muitos anos.

\begin{abstract}
A Havaianas é uma marca que eu me lembro de infância, de muitos, muitos anos. Tenho vários produtos, todos os meus chinelos são da Havaianas, todos! Eu sou de uma cidade do interior e quando eu era criança todo mundo usava! Isso lá em 1970! (Entrevista 10)
\end{abstract}

Ao questionar como os entrevistados descreveriam a marca Havaianas, muitos classificaram a marca como tradicional, prática, diversificada, de boa qualidade, bonita e "a cara" do Brasil.

"A: Marca clássica, criativa, chique, confiável! B: Boa! Faz o que se compromete a fazer. Bem funcional." (Entrevista 7)

"Acho que a Havaianas sempre teve pra mim uma coisa associada a simplicidade e a baixo custo. São produtos de boa qualidade, com um custo acessível e é superconfortável." (Entrevista 10)

"É uma marca muito versátil, que pode ser usada em qualquer ambiente. Se adapta ao gosto do consumidor. É uma marca que tá crescendo muito no mundo por essa dinamicidade." (Entrevista 1)

"Acho que é uma marca que tem muita identidade com o povo brasileiro, é uma marca tradicional né? É muito mais que uma marca, é uma coisa que as pessoas se identificam e identificam o país através dela." (Entrevista 12)

As respostas mostraram que a marca Havaianas possui um branding muito bem estruturado em linha com Solomon (2016), de modo que os 
consumidores associam a marca a experiências memoráveis, recompensadoras e de afeição, reconhecendo com facilidade a essência da marca, sabendo colocar em palavras a imagem que construíram ao longo dos anos. Além disso, é possível notar que a marca estabeleceu um relacionamento com seus consumidores através da ligação de autoconceito, se tornando parte da identidade do carioca, do brasileiro, se tornando símbolo da cultura; através da ligação nostálgica, conectando o consumidor com experiências positivas da infância; também se conectando pela interdependência, sendo parte da rotina diária dos consumidores que vivem em uma cidade praiana; e pelo amor, tendo consumidores que elaboram livremente seu afeto pela marca e os produtos, sendo fidelizados e atentos as novidades.

\subsubsection{Percepção e atitude após a visita à loja conceito}

Ao final da entrevista, após questionar os entrevistados sobre os elementos percebidos na loja conceito em relação ao espaço, a estética, o atendimento e os produtos (tópicos analisados nos itens seguintes a esse), os respondentes foram convidados a refletir se a sua percepção da marca mudou a partir da experiência vivenciada. Quase metade dos entrevistados não considerara que sua percepção mudou, mas sim que foi reforçada por meio da loja conceito, tornando mais material a imagem da marca construída ao longo dos anos.

\footnotetext{
Acho que não mudou muito minha percepção da marca por eu já conhecer bastante, mas acho que mudaria se eu fosse um comprador novo, acho que acaba sendo uma vitrine principalmente pros gringos como a outra flagship store da Oscar Freire (SP). (Entrevista 2)
}

É importante destacar que de acordo com Kotler e Keller (2012), a percepção de marca é influenciada pela distorção seletiva e pela retenção seletiva, que beneficiam marcas fortes como a Havaianas, de modo que os consumidores tendem a associar produtos de boa qualidade à marca e a perceber apenas elementos positivos em relação aos produtos que gostam.

Alguns dos entrevistados destacaram o marketing da marca Havaianas como um diferencial, reconhecendo a marca como inteligente e atualizada de 
acordo com as tendências do mercado, principalmente em relação aos comerciais e propagandas, além da participação da marca em eventos e na construção da experiência de compra para o consumidor.

Eu sempre achei uma marca muito inteligente, que sempre investiu em bons comerciais e propagandas. O marketing da Havaianas é muito bom, acho que ajudou muito a ganhar a proporção que tem hoje tendo um produto muito simples né? (Entrevista 1)

Não mudou muito a minha percepção porque eu acho que a Havaianas tá sempre inclusa em atualidades. Acho que a Havaianas é uma marca que tá sempre se atualizando por isso que ela fica no mercado e é a preferida pra muita gente. A loja conceito acaba reforçando isso. (Entrevista 8)

Porém, o restante dos entrevistados, compondo mais da metade dos respondentes, afirmaram que a experiência na loja conceito mudou a sua percepção e atitude sobre a marca. Essa mudança aconteceu principalmente para os consumidores que não acompanham a marca e suas ações de perto e que não tinham uma percepção sólida do crescimento da marca Havaianas nos últimos anos.

Pior que mudou sim. Eu estava vendo a Havaianas decaindo, com outra visão. Eu sei que é uma marca que já tá muito sólida no mercado e essa loja me fez perceber que eles ainda estão aqui firmes e fortes, que estão no mercado pra ganhar. (Entrevista 9)

Talvez tenha acrescentado o quanto a marca cresceu ao longo do tempo. Mudou o status da Havaianas quanto marca. Acho que ficou mais forte isso pra mim, deixou em pé de igualdade com marcas muito de grifes, sabe? Acho que a gente ver uma loja tão grandiosa acrescenta sim, parece que a gente tá em Nova York! É um negócio muito grande e da vontade de voltar pra ver se vamos ter as mesmas sensações. (Entrevista 10)

Além disso, alguns consumidores ficaram surpresos com o portfólio da marca por não conhecerem as coleções de roupas e acessórios, como peças de 
linho, roupas de banho e óculos escuros. Outros mencionaram que a marca está com um posicionamento mais "premium" o que acaba afetando a percepção do preço dos produtos e fazendo o consumidor questionar o papel da marca no mercado e a comparar a marca com o que era antigamente, com produtos mais básicos e tradicionais.

A: O que é interessante que a Havaianas tá tão no sangue da gente né, consumidores fiéis que acho que nem precisa tanto disso, mas é legal, muito chique! B: Aliás, pra mim a dificuldade é a Havaiana ficar chique desse jeito. A: É, ele já disse assim: não vamos lá que vai ser muito mais caro, e na verdade nem é né? Os modelos clássicos são o mesmo preço que você encontra em qualquer esquina e isso é bem interessante! B: Pra mim me dá a impressão que eu to pagando por tudo isso aqui né? Por uma Havaiana super produzida. (Entrevista 7)

A minha percepção da Havaianas tem mudado, porque pra mim era uma marca muito popular e que foi ganhando reconhecimento e tentando abranger novas situações de uso, porque a princípio era aquele chinelinho clássico e ai eles fizeram vários modelinhos mais esbeltos, mais delicados que você pode usar não só pra ir na esquina ali, mas também pra sair... enfim, eles aprimoraram os produtos, requintando, encarecendo e atingindo outros grupos de compra. Tem até Havaianas com pedrinhas Swarovski, né? Então, a minha percepção da Havaianas é um pouco isso, essa transição que eu vi mesmo. (Entrevista 14)

\subsection{Análise da percepção do consumidor sobre o ponto de venda}

É importante destacar o ponto de venda associado à imagem da marca para os consumidores entrevistados. A quarta pergunta da entrevista se referia ao local onde o consumidor costuma comprar produtos da Havaianas. De acordo com Lovelock et al. (2011), existem elementos que ajudam na construção da experiência na loja em ambientes varejistas, tanto externos, como localização e acessibilidade, quanto internos, como iluminação, aromas, cores e disposição dos produtos. Como a Havaianas atua em pontos de venda muito diversos, desde lojas em shoppings até as bancas de jornal, os consumidores relataram diferentes experiências relacionadas ao momento de compra, aos produtos que 
desejavam encontrar e a percepção do preço. Alguns consumidores relataram que já tinham o costume de comprar os produtos das Havaianas nas lojas da marca, buscando por variedade, conforto e bom atendimento normalmente em shoppings e galerias.

"Compro normalmente nas lojas da Havaianas, quase sempre no Barra Shopping. É que na verdade nas lojas da Havaianas você tem os produtos mais novos, as novas coleções e modelos." (Entrevista 1)

Outros consumidores preferem estabelecimentos como supermercado ou bancas de jornal, buscando por um preço mais baixo e pelos produtos mais básicos. Além disso é importante reforçar que a maior concentração das lojas da Havaianas está localizada na Zona Sul do Rio de Janeiro, o que faz com que os consumidores busquem pelos produtos em outros pontos de venda.

\footnotetext{
Quando eu morava com a minha mãe eu costumava comprar em lojinha, venda, porque não tinha muito acesso a esse mercado da Havaianas em loja, o meu acesso era em papelaria, bancas de jornal. Ai hoje em dia quando eu preciso vou em lojas mesmo da Havaianas perto do trabalho, aqui em Ipanema ou no shopping. (Entrevista 11)
}

A partir das respostas pode-se concluir que a necessidade é um grande motivador de compra no caso da Havaianas, pois até mesmo os consumidores que buscam os produtos mais novos também se sentem confortáveis de encontrar os chinelos da marca em diversos pontos de venda.

"Eu normalmente compro na loja da Havaianas do shopping Leblon ou do Barra Shopping. As vezes compro até em banca porque tenho um cachorro que está sempre comendo as Havaianas então sempre to comprando." (Entrevista 8)

Além disso, a loja conceito da Havaianas na Rua Garcia D'Ávila está posicionada em um espaço movimentado de compras, próxima a lojas conceito, de modo similar à loja da marca em São Paulo, na Rua Oscar Freire. A localização é muito importante na concepção das lojas conceito, sendo uma característica importante para se diferenciarem no varejo, de acordo com Manlow e Nobbs (2012). Alguns entrevistados mencionaram a localização da loja 
conceito como um diferencial, considerando principalmente o bairro de Ipanema estratégico para o contato com os estrangeiros que costumam procurar a marca ao visitarem o Brasil. Além disso, alguns consumidores também destacaram que a loja é um ponto de venda mais agradável tendo como principais atrativos o visual, o atendimento e a variedade de produtos. Muitos dos entrevistados eram moradores de Ipanema, preferindo frequentar a loja também pela proximidade.

\begin{abstract}
B: É uma flagship store né? Eles investem bastante e mesmo que não gere lucro é uma loja que pelo marketing já tem o retorno que eles querem. Porque é caro manter uma loja desse tamanho numa localidade como essa. A: É bem estratégico porque é cheio de gringos aqui. $E$ é aquilo né, eu sei que vende Havaianas no jornaleiro, mas prefiro vir comprar na loja bonitinha. B: Acaba virando um programa ligado a experiência do consumidor apesar de ser o mesmo produto e o mesmo preço. (Entrevista 2)
\end{abstract}

\title{
4.5.Análise do entendimento do consumidor sobre lojas conceito
}

Os entrevistados foram convidados a descrever o que entendem como sendo uma loja conceito. Muitos já conheciam o termo e em linha com Kozinets et al. (2002), esses consumidores entendem a loja conceito como um espaço desenvolvido para construir e reforçar a imagem da marca e não apenas para vender os produtos.

Conheço o termo porque fiz arquitetura. A loja conceito é pra você fazer a propaganda da marca, né? Não é nem questão de vender os produtos em si, é trazer os conceitos da marca, os ideais, a estética... é mais uma vitrine do que a marca representa do que a venda dos produtos em si. (Entrevista 1)

Uma loja conceito é uma loja que não vai ficar lá pra sempre, ela vai ta lá pra proporcionar mais uma experiência do que vender o produto, é mais uma coisa de awareness, como se fosse um museu da marca. (Entrevista 8)

Houve também entrevistados que afirmaram terem ido à loja por saberem dessa denominação e terem ficado curiosos sobre o que iriam encontrar, 
mostrando que a loja conceito da Havaianas está em linha com a estratégia de divulgação da marca através da loja conceito, abordada por Manlow e Nobbs (2012).

Eu já sabia que era uma loja conceito, e por isso vim e busquei saber o que a loja tinha de diferente, se é uma loja modelo, uma loja que vai carregar o conceito único pra ela pra te proporcionar uma experiência diferente. Acho que é o diferencial da loja, me chamou atenção por saber que tinha uma proposta por trás... (Entrevista 11)

A: A gente veio só pra conhecer a loja mesmo, não viemos pensando em comprar nada. Eu vi no Instagram a parede colorida que me chamou a atenção e também a fachada da rua que achei interessante. Pra mim uma loja conceito é uma loja que não só instiga as pessoas a comprarem, mas é uma coisa bem lúdica, né? É como se fosse uma identidade da marca palpável em que você imerge nessa identidade visual... Eu não sei se considero essa loja da Havaianas uma loja conceito por que não é tão abstrata sabe? (Entrevista 15)

Outros entrevistados não conheciam o termo e foram informados pelos atendentes da loja, que explicam o que é a loja conceito e quais são os objetivos da marca por meio dela.

Eu já tinha ouvido esse termo, mas nunca tinha parado pra entender. Aí a moça aqui da loja me explicou que é essa loja onde tem todos os produtos. Ela falou que tem duas, uma aqui e a outra é em São Paulo. Eu entendi que é quando você consegue ver o todo da Havaianas né, consegue passar por todas as criações, ter uma visão de toda a marca. Porque parece que as lojas têm um pouquinho aqui, um pouquinho ali, aqui você tem acesso à toda a criação. (Entrevista 10)

A partir das respostas é possível identificar que os entrevistados entendem o que é a loja conceito e a maioria consegue identificar na loja da Havaianas a imagem da marca que está sendo passada, que acabou 
impactando na percepção do consumidor sobre a Havaianas ou reforçando uma imagem já construída.

\subsection{Análise da experiência do consumidor na loja conceito}

A loja conceito da Havaianas pode ser enquadrada no reino da Estética nos Quatro Reinos do Marketing de Experiências de Pine e Gilmore (2011), pois o indivíduo participa fisicamente da experiência, porém não a afeta ou influencia diretamente. Portanto, a loja se fortalece nos elementos estéticos, arquitetônicos, nos produtos e no atendimento diferenciado para proporcionar uma experiência única para o consumidor.

$\mathrm{Na}$ entrevista, os respondentes foram convidados a relatar a sua experiência na loja conceito de forma geral, depois foram questionados sobre elementos que afetaram os seus sentidos, como cores, música, cheiros, iluminação do ambiente e temperatura. Além disso, foram questionados sobre o que acharam do atendimento, do visual e da estética da loja, dos produtos, da mobilidade e do espaço. De acordo com Lovelock et al. (2011), as lojas varejistas possuem diferentes dimensões que ajudam na construção da atmosfera ideal de compra: Instalações Exteriores, Interior da Loja, Disposição da Loja, Expositores Internos e Dimensões Sociais. Cada dimensão será analisada nos tópicos seguintes a partir dos relatos dos entrevistados sobre a experiência na loja.

\subsubsection{Instalações Exteriores}

Para as Instalações Exteriores, são pontos importantes o estilo arquitetônico da loja, a fachada atraente de modo que gere visibilidade (LOVELOCK et al., 2011). De acordo com as entrevistas, é interessante destacar que a fachada toda preta da loja faz com que o consumidor fique impactado com as cores do interior, se sentindo instigando a conhecer toda a loja, em linha com a proposta do arquiteto Isay Weinfeld.

Quando você vai numa loja da Havaianas você já sabe mais ou menos o que esperar. A loja é aberta, ventilada, clara e você consegue visualizar todos os produtos até de fora. E nessa loja não, além de ser toda escura por fora ela cresce verticalmente, então você sobe a escada pra descobrir o que tem no próximo 
andar, e é muito curioso porque todo o design da loja é diferente. (Entrevista 11)

\subsubsection{Interior da Loja}

O Interior da Loja é composto pelos esquemas de cor, iluminação, aromas, sons e música, acessórios e texturas nas paredes, a composição do teto, temperatura do ambiente, limpeza, disposição e organização dos provadores e os acessos através de elevadores ou escadas (LOVELOCK et al., 2011).

Dentre os Módulos Estratégicos Experienciais abordados por Schmitt (1999), as experiências sensoriais (sense) são as que mais se destacam na loja conceito da Havaianas, gerando uma experiência baseada nos cinco sentidos e nos estímulos sensoriais do ambiente: luz, cores, sons, odores. Cada indivíduo recebe esses estímulos de maneira única, identificando os que mais captam a sua atenção. Esses estímulos são essenciais para a criação de uma experiência que perdure por um longo prazo na mente do consumidor.

As cores sem dúvida são o principal diferencial da loja, estando associadas ao design, a arquitetura e a estética do ambiente. A parede com as Havaianas em degrade foi citada em todas as entrevistas como o elemento que mais chama a atenção e mais encanta o consumidor. É interessante reparar que o degrade da parede de Havaianas começa com cores frias no primeiro andar e termina com cores quentes no terceiro, ajudando a criar uma atmosfera de compras tropical e condizente com a imagem da marca.

Quanto a decoração eu consigo identificar essa mudança de cores nas Havaianas de um ambiente pro outro, que é quase uma escultura na parede inteira, do primeiro andar até o terceiro com as Havaianas com esse degrade de cor. Também o fato do terceiro andar ter som ambiente diferente e muda junto com as cores das Havaianas na parede, passa um clima bem veraneio também com as estampas e cores quentes. (Entrevista 11)

O paredão de Havaianas! É muito legal! É o que chama mais atenção na loja, parece um mosaico só de Havaianas. A loja é grande, espaçosa, artística. A loja do Barra Shopping é colorida mas é mais simplória. Essa aqui tem toda uma estética né? $A$ 
loja é muito linda, é a loja de Havaianas mais bonita que já vi. (Entrevista 1)

A partir das entrevistas é possível identificar que nem todos os respondentes notaram a música no ambiente. As músicas que tocam na loja são brasileiras, têm um ritmo mais acelerado e gostoso de ouvir, o que ajuda a tornar a experiência na loja mais agradável, além de associar a marca à cultura brasileira. Muitos dos entrevistados perceberam o som de mar no terceiro andar da loja o que reforçou bastante a imagem da marca associada ao tropical e ao Rio de Janeiro.

"Gostei da música que estava rolando, da vontade de comprar! Música toda animada, parecendo que a vida é toda maravilhosa!" (Entrevista 10)

Outro elemento que também passou despercebido por alguns entrevistados foi o aroma. A Havaianas têm um aroma muito característico da marca e é muito interessante notar que para alguns consumidores acabou passando sem ser notado. Já é esperado que o aroma passe despercebido, porém, ainda assim, é capaz de despertar respostas emocionais e gerar um impacto no comportamento de compra. Sendo a Havaianas uma marca muito relacionada à infância e a memórias de longo prazo, o aroma usado nas lojas e nos produtos provavelmente desperta essas lembranças e impacta o consumidor de forma inconsciente.

"Sempre que eu vou em uma loja eu tento perceber identidade olfativa e eu acho legal as lojas investirem nisso, é como se você carregasse uma memória olfativa pros clientes." (Entrevista 11).

É interessante observar que por mais que seja possível abordar cada elemento sensorial separadamente, o que de fato gerou impacto para os entrevistados foi o conjunto: cores, cheiros, música, arquitetura, atuando em conjunto para criar uma experiência diferenciada.

No primeiro momento você fica meio fascinado né? É muita coisa na sua frente, muito colorido, muita informação... acho que a loja apesar desse excesso de informação instiga mais a conhecer, a subir e a ver o que tem lá no último andar. É 
instigante mesmo. Acho que a loja conceito te pega nesse sentido, por ser sensorial. (Entrevista 14)

\subsubsection{Disposição da Loja e Expositores Internos}

A dimensão Disposição da Loja deve considerar o posicionamento dos produtos, a localização do caixa e as áreas de fluxo. Expositores Internos engloba a forma como os produtos estão expostos e os preços, assim como estantes e caixas. (LOVELOCK et al., 2011).

$\mathrm{Na}$ loja conceito da Havaianas, os entrevistados destacaram principalmente a disposição dos produtos em diferentes andares. O caixa fica localizado no térreo, na entrada da loja. No primeiro andar estão as sandálias clássicas, alpargatas e as Havaianas licenciadas. No segundo andar estão as Havaianas especiais, acessórios, além de roupas de linho e algodão. Por fim, no terceiro além das sandálias, estão expostos óculos escuros, roupas de banho e sandálias infantis. Grande parte dos entrevistados achou essa divisão interessante e a dimensão da loja impactante de forma positiva, gerando curiosidade de descobrir o que tinha em cada andar.

"O espaço é bem organizado, o que torna a loja mais funcional né? Gosto bastante da dinâmica da loja com os três andares, acho que é fácil de entender." (Entrevista 1)

Entretanto, alguns consumidores relataram se sentirem incomodados com a grandiosidade da loja e com a disposição dos produtos dividida por andares.

\footnotetext{
A loja é linda, mas achei muito dividida em seções. Primeiro andar é só chinelo, segundo é uma roupinha mais arrumadinha e lá em cima é a moda praia né? Acho que não precisava daquele mundo todo, até porque a gente acaba vendo de pouquinho em pouquinho. É gostoso quando a gente vê todos os produtos juntos. (Entrevista 10)

Eu sei que aqui eles sempre vão ter mais produtos, mais variedade e eu sei que provavelmente vou encontrar alguma coisa diferente do comum, tipo se eu quiser dar um presente pra alguém. Eu gostei do espaço, mas talvez eu preferiria se
} 
fosse mais amplo, sabe? Com menos andares. Eu fiquei impressionada porque a loja era maior do que eu esperava, acho que seria mais legal se fosse tipo uma loja gigante num nível só ao invés de vários andares medianos. Eu acho que daria um impacto maior, uma sensação de grandeza que chamaria mais a atenção. (Entrevista 12)

\subsubsection{Dimensões Sociais}

A categorização de Dimensões Sociais está relacionada aos funcionários, a forma de interação, o uniforme dos atendentes, a privacidade e o autosserviço. (LOVELOCK et al. 2011).

A maioria dos entrevistados notou o atendimento como um diferencial, ajudando o consumidor a ter a experiência completa da loja. Os atendentes convidam os consumidores a subir todos os andares e a conhecerem todo 0 portfólio da Havaianas. Explicam aos clientes sobre a loja e qual a ideia por traz da arquitetura e do design. Isso faz com que os consumidores fiquem mais engajados e entregues a experiência.

\footnotetext{
"A experiência foi ótima, em todos os andares me senti super bem atendida, mas achei que tem muita gente e na hora que você chega as pessoas já vem e eu não fiquei tão à vontade. São todos muito bem treinados pra ir te contando como funciona, que você pode ir no elevador, te explicam o que é a loja conceito, te mostram os produtos, e eu fiquei impressionada por que tinham muitos gringos e eles precisam dar conta né?" (Entrevista 10)
}

\subsubsection{Ambiente Holístico}

A partir das entrevistas, pode-se considerar que os consumidores tiveram experiências positivas na loja conceito da Havaianas. A loja oferece um Ambiente Holístico ao consumidor, desde a fachada exterior que gera uma curiosidade e um interior de loja que considera esquemas de cor, aromas, sons, acessórios e texturas das paredes, de modo que todos os elementos conversam entre si, desde o acesso às escadas e o elevador até a composição do teto do terceiro andar com iluminação natural. 
"A loja é ótima, o que me fez vir novamente foi trazer outras pessoas para ter essa experiência, porque é uma experiência única de loja eu acho. As cores em degrade, tudo com o conceito da Havaianas e fundamentado na marca é uma experiência sem comparação." (Entrevista 9)

"Achei a loja bonita, achei interessante visualmente, acho que dá pra ter uma boa noção do que é a Havaianas. Acho que a loja conceito agrega visualmente porque tem um design legal, uma arquitetura legal, mas eu fico me perguntando se os produtos não acabam ficando em segundo plano... Se bem que no caso da Havaianas isso não acontece tanto pelas Havaianas na parede né? Acho que uma coisa agrega a outra, é uma junção das duas coisas, o produto torna a loja visualmente legal apesar da loja ter uma estrutura arquitetônica e de design bem maneira também." (Entrevista 14) 


\section{Conclusões e recomendações para novos estudos}

As lojas conceito têm se tornado uma forma das marcas expressarem sua essência e seus valores para o consumidor de forma material, através de experiências e sensações que gerem memórias de longo prazo e que fortaleçam a afetividade com seus produtos.

O presente estudo propôs avaliar a percepção e atitude dos consumidores sobre a marca Havaianas a partir das experiências oferecidas pelo Espaço Havaianas Rio, a loja conceito da marca, localizada em Ipanema, no Rio de Janeiro. Para isso, foram consultados autores que abordam temas como branding, brand equity, comportamento do consumidor, estímulos de marketing, percepção, atitude, marketing de experiências, atmosfera de compras, a loja conceito e suas principais características e estratégias.

Para atingir o objetivo final do estudo foi realizada uma pesquisa exploratória com consumidores da marca Havaianas, logo após a sua visita à loja conceito em Ipanema. Foram no total 22 respondentes, agrupados em 15 entrevistas por terem sido realizadas individualmente ou em grupo. Os respondentes foram convidados a compartilhar a sua percepção sobre a marca Havaianas antes e depois da visita à loja conceito, além de compartilharem suas percepções e atitudes sobre os elementos sensoriais que construíram a sua experiência na loja.

Conforme conversado com um dos atendentes da loja, a intenção da loja conceito da marca Havaianas é ser um espaço onde os consumidores possam encontrar todos os produtos expostos, sendo fácil para o cliente encontrar o que procura e conhecer as novidades $O$ atendente explicou que muitas pessoas se surpreendem ao entrar na loja por verem a caixa preta do lado de fora e no interior se depararem com tantas cores. A parede de Havaianas é composta por 2700 pares e acompanha o cliente do primeiro até o terceiro andar. A ideia da loja é proporcionar uma experiência diferenciada para cada cliente.

A partir das teorias estudadas e das entrevistas realizadas, parece que o Espaço Havaianas Rio cumpre sua proposta, sendo reconhecido pelos consumidores como um ambiente varejista diferenciado, que cria uma experiência através dos sentidos, com o uso de cores, sons e cheiros, além de se destacar pelo atendimento e variedade de produtos. A arquitetura da loja e o design interior foram as características mais citadas nas entrevistas, 
como algo que desperta a curiosidade do cliente a conhecer todos os andares da loja e a descobrir quais são os produtos que podem encontrar. Apesar do cheiro e da música não terem sido percebidos por todos os entrevistados, são detalhes que fazem parte da construção da experiência e influenciam o comportamento do consumidor, despertando sensações e ajudando a manter um ritmo de compra mais rápido e descontraído na loja conceito.

Assim, a loja conceito transmitiu para os consumidores 0 crescimento da marca nos últimos anos, o investimento da marca em ampliar o seu portfólio de produtos, a intenção da marca de se posicionar de forma premium no mercado e o papel da marca como uma representação do carioca e do Brasil, cultivando valores como diversidade e conforto, inovando sem deixar de lado a tradição e a qualidade.

A percepção e atitude do consumidor sobre a marca Havaianas parece ter mudado após a visita à loja conceito para a maioria dos entrevistados de forma positiva. A loja conceito transmite para o consumidor uma imagem de grandeza e modernidade, mostrando que a marca está expandindo seus horizontes, investindo em novos produtos e atingindo novos consumidores.

\subsection{Implicações gerenciais}

A partir do presente estudo, pode-se compreender que a imagem da marca pode ser passada com elementos visuais que são percebidos facilmente, sendo uma boa forma de despertar a atenção do cliente e estabelecer uma primeira conexão. É importante considerar elementos visuais que sejam "Instagramáveis", o que torna a experiência mais atrativa e impulsiona a divulgação espontânea da loja nas redes sociais. Elementos como cheiros e sons são importantes para ajudar a dar vida a imagem da marca, criando uma experiência que envolva todos os sentidos. $O$ atendimento também é um diferencial para a experiência completa na loja, sendo percebido pelos clientes, podendo tornar o momento da compra mais agradável.

Assim, é importante que a marca busque desenvolver uma loja conceito que esteja bem alinhada com sua imagem e seus valores, para que os consumidores consigam a partir essa experiência, ter uma ideia mais clara do que é a marca e atribuam maior valor agregado os seus produtos. A 
experiência oferecida por uma loja conceito pode ser mais lúdica, como a Galeria Melissa, mais varejista, como o Espaço Havaianas Rio, e até mais tecnológica como a Amazon Go, por isso cabe a cada marca entender qual formato dialoga melhor com seu público alvo se adequa mais as suas estratégias de marketing.

\subsection{Recomendações para novos estudos}

Como recomendações para estudos futuros acerca do tema, podem ser desenvolvidas pesquisas que busquem identificar como as diferentes lojas conceito são reconhecidas pelos consumidores e qual modelo de loja mais de adequa a estratégia de cada marca e quais elementos devem ganhar mais destaque em cada formato. Outra sugestão seria ter uma visão interna da marca sobre os resultados obtidos com a loja conceito, buscando entender como esse investimento é mensurado, quais são os principais objetivos da marca a partir da loja conceito, quais são as estratégias por trás do seu desenvolvimento e como a marca busca construir uma experiência diferenciada para o consumidor. 


\section{Referências Bibliográficas}

AAKER, D. Managing Brand Equity, 1991

ALMAPBBDO. Havaianas inaugura loja conceito no Rio de Janeiro. 2018, Disponível em: <https://almapbbdo.com.br/pt/trabalhos/havaianas-inaugura-lojaconceito-no-rio-de-janeiro+285 >. Acesso em: 28 de Abril de 2019.

MACHADO, M. BH1.O Marketing da Marca Havaianas: criando brand equity por meio de emoção e valores culturais. 2018.

Disponível em: <http://www.bh1.com.br/administracao-de-marketing/o-marketingda-marca-havaianas/>. Acesso em: 05 de Maio de 2019

BLESSA, R. Merchandising no ponto de venda. São Paulo, Atlas, 2003

DURANTE, S.; ROCHA, I. Havaianas inaugura loja conceito no Rio de Janeiro. Revista Casa e Jardim, 2018. Disponível em: $<$ https://revistacasaejardim.globo.com/Casa-e-

Jardim/Arquitetura/noticia/2018/09/havaianas-inaugura-loja-conceito-no-rio-dejaneiro.html>. Acesso em: 28 de Abril de 2019

GIL, A. C. Métodos e Técnicas de Pesquisa Social: 5ed. São Paulo: Atlas, 2008

HAVAIANAS. A História. Disponível em: <https://www.havaianas.com.br/ahistoria>. Acesso em: 10/07/19

KOTLER, P. et al. Marketing 4.0. Do Tradicional ao digital: GMT Editores Ltda, 2017

KOTLER, P. et al. Marketing 3.0. As forças que estão definindo o novo marketing centrado no ser humano. 2010

KOTLER, P.; ACHROL, R. Frontiers of the marketing paradigm in the third millennium, P 37, Academy of Marketing Science, 2011

KOTLER, P.; KELLER, K. Adminitração de Marketing, 2012

KOZINETS, R.V. et al. (2002). Themed flagship brand stores in the new millennium: theory, practice, prospects. Journal of Retailing 78, 2002

LOKEN, B. Consumer Psychology: Categorization, Inferences, Affect, and Pesuasion. Annul Review of Psychology 57, 2006

LOVELOCK, C. et al. Marketing de Serviços, pessoas, tecnologia e estratégia. 2011. 
MANLOW, V.; NOBBS, K. Form and function of luxury flagships: An international exploratory study of the meaning of the flagship store for managers and customers. Journal of Fashion Marketing and Management. Vol. 17 No. 1.2013.

MOORE, C. et al. Flagship stores as a market entrymethod: the perspective of luxuryfashion retailing, UK, 2008.

O NEGÓcIO DO VAREJO. As estratégias por trás das lojas conceito. 2014 Disponível em: <http://onegociodovarejo.com.br/estrategias-por-tras-daslojas-conceito/ >.Acesso em: 05 de Maio de 2019

PINE II, B. J.; GILMORE, J. H. Welcome to the experience economy. Boston: Harvard Business Review, 2011.

ROBERTS, K. Lovemarks: o futuro além das marcas. Books do Brasil Editora LTDA, 2005.

SEBRAE. Calçados Femininos, Relatório de Inteligência 2015. Disponível em:

$<$ http://www.bibliotecas.sebrae.com.br/chronus/ARQUIVOS CHRONUS/bds/bds. nsf/df38c52f6c632ed88a5b019b506aca80/\$File/5377.pdf>. Acesso em: 05 de Maio de 2019

SEBRAE. Saiba mais sobre as lojas conceito: uma das tendências do varejo. $2015 \quad$ Disponível em:<http://www.sebrae.com.br/sites/PortalSebrae/artigos/saiba-mais-sobre-aslojas-conceito-uma-das-tendencias-dovarejo,f31dae21e224f410VgnVCM1000004c00210aRCRD>.Acesso em: 05 de Maio de 2019

SCHMITT, B. Experience Marketing: Concepts, Frameworks and Consumer Insights. Foundations and Trands in Marketing, 2011

SCHMITT, B. The Journal Of Marketing Manegement, p57. 1999

SOLOMON, M. R. O comportamento do consumidor: comprando, possuindo e sendo. 11a edição. Bookman, 2016

UNDERHILL, PACO. Vamos às Compras!. 2009 


\section{Anexo 1}

Entrevista - Loja Conceito da Havaianas

Olá, me chamo Fernanda. Sou aluna de Administração da PUC e estou fazendo uma pesquisa sobre consumidores e marcas. Você se incomodaria em responder algumas perguntas? A pesquisa é anônima e as respostas serão gravadas para que depois me ajudar a lembrar de tudo que você respondeu.

1) Você já conhecia a marca Havaianas? Tem algum produto da marca? Você lembra quando foi a $1^{\mathrm{a}}$ vez que teve contato com a marca Havaianas?

2) Como você descreveria a Havaianas como marca?

3) Você se identifica com a marca? E com os produtos?

4) Onde você costuma comprar os produtos da Havaianas?

5) É a sua primeira vez nessa loja? O que você achou dela?/O que te fez vir novamente?

6) O que the fez procurar essa loja Havaianas e não outra?

7) O que te chamou mais atenção dentro da loja?

8) Como você relataria a sua experiência? Como você se sentiu dentro da loja?

9) Você percebeu elementos que afetaram os seus sentidos (cores, música, cheiros, iluminação, temperatura do ambiente)?

10) Você comprou algum produto na loja? Se sim, é um produto que você já estava planejando comprar ou você decidiu levar na hora?

11) Você viu algum comercial, teve indicação de amigos, ou viu algum post em rede social que te levou a esse produto?

12) $O$ que achou do atendimento?

13) O que achou do visual/estética?

14) $O$ que achou dos produtos?

15) O que achou do espaço/mobilidade?

16) Você já ouviu o termo "loja conceito"? O que entende por isso?

17) Você considera essa loja da Havaianas uma loja conceito?

18) A sua percepção sobre a marca Havaianas mudou depois da visita a essa loja?

Perguntas filtro: Idade, gênero e bairro de moradia. 